\title{
Independent Technical Review and Analysis of Hydraulic Modeling and Hydrology Under Low-Flow Conditions of the Des Plaines River Near Riverside, Illinois
}

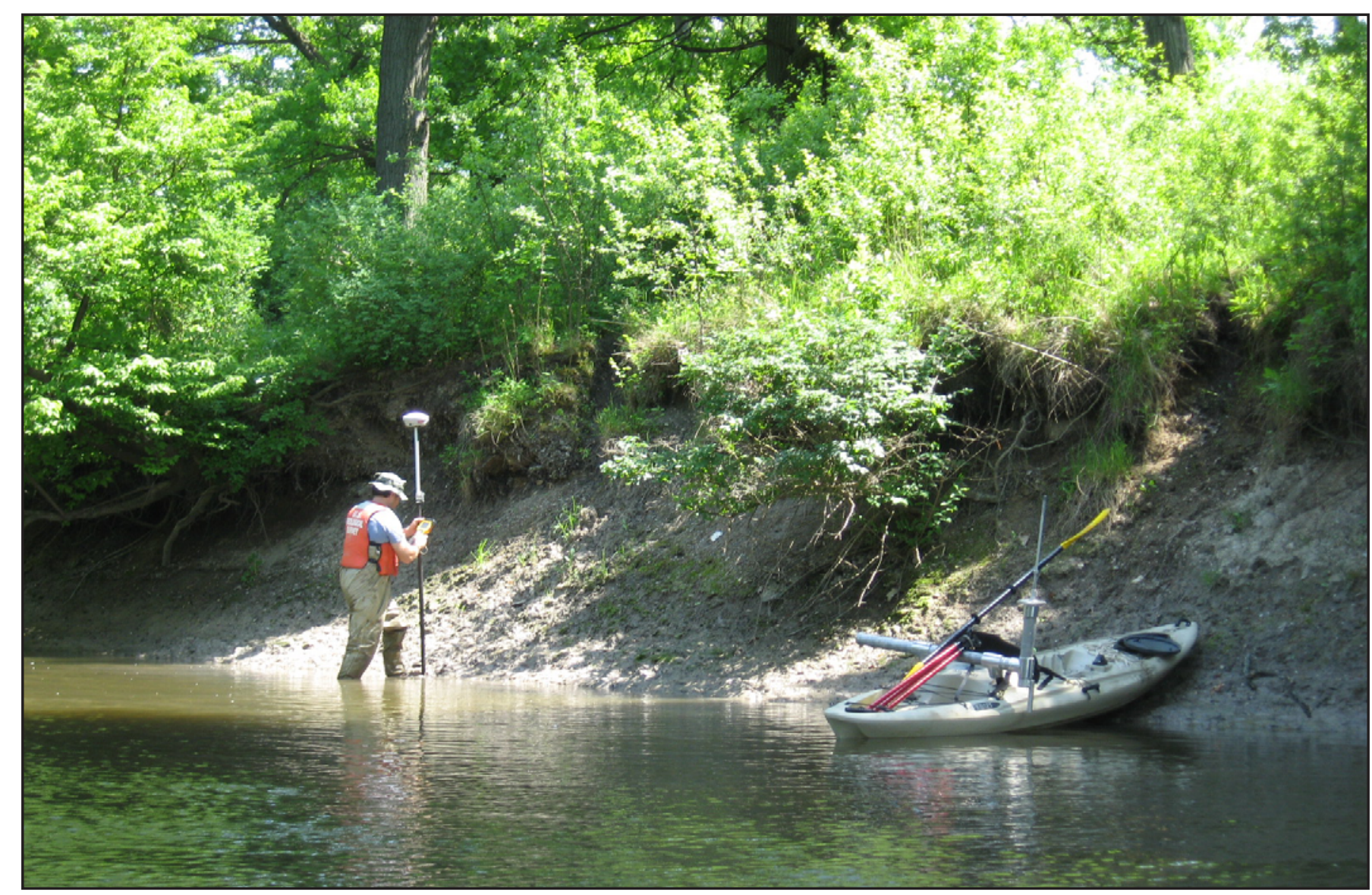

Open-File Report 2012-1143 
Photo on covers shows a USGS Hydrologist obtaining water-surface elevations along the Des Plaines River near Riverside, Illinois with a Global Positioning System (GPS).

(Photo by Jon Hortness, USGS-Ilinois Water Science Center). 


\section{Independent Technical Review and Analysis of Hydraulic Modeling and Hydrology Under Low-Flow Conditions of the Des Plaines River Near Riverside, Illinois}

By Thomas M. Over, Timothy D. Straub, Jon E. Hortness, and Elizabeth A. Murphy

Open-File Report 2012-1143 


\title{
U.S. Department of the Interior \\ KEN SALAZAR, Secretary \\ U.S. Geological Survey \\ Marcia K. McNutt, Director
}

\author{
U.S. Geological Survey, Reston, Virginia: 2012
}

For more information on the USGS - the Federal source for science about the Earth, its natural and living resources, natural hazards, and the environment, visit http://www.usgs.gov or call 1-888-ASK-USGS.

For an overview of USGS information products, including maps, imagery, and publications, visit http://www.usgs.gov/pubprod

To order this and other USGS information products, visit http://store.usgs.gov

Any use of trade, firm, or product names is for descriptive purposes only and does not imply endorsement by the U.S. Government.

Although this information product, for the most part, is in the public domain, it also may contain copyrighted materials as noted in the text. Permission to reproduce copyrighted items must be secured from the copyright owner.

Suggested citation:

Over, T.M., Straub, T.D., Hortness, J.E., and Murphy, E.A., 2012, Independent technical review and analysis of hydraulic modeling and hydrology under low-flow conditions of the Des Plaines River near Riverside, Illinois: U.S. Geological Survey Open-File Report 2012-1143, 73 p. 


\section{Contents}

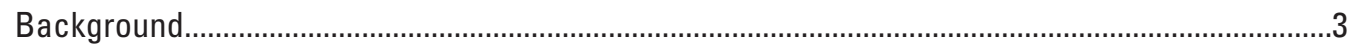

Field Data Collection During Low-Flow Conditions ...................................................................

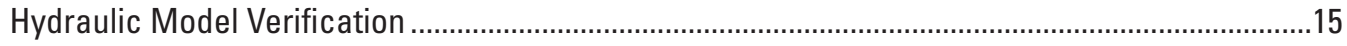

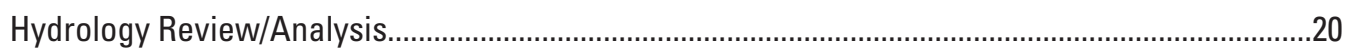

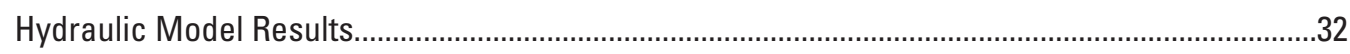

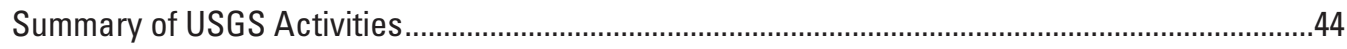

Hydrologic Analysis: Additional Methods and Results Slides ……............................................50

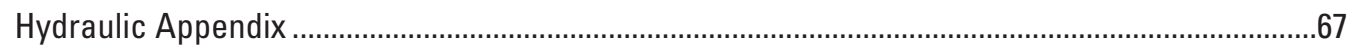

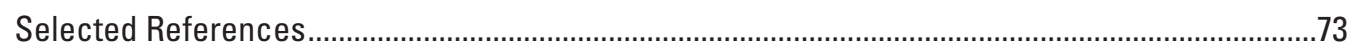




\section{Conversion Factors and Abbreviations}

Inch/Pound to SI

\begin{tabular}{lcl}
\hline \multicolumn{1}{c}{ Multiply } & By & \multicolumn{1}{c}{ To obtain } \\
\hline foot $(\mathrm{ft})$ & Length & \\
mile $(\mathrm{mi})$ & 0.3048 & meter $(\mathrm{m})$ \\
\hline & 1.609 & kilometer $(\mathrm{km})$ \\
\hline square mile $\left(\mathrm{mi}^{2}\right)$ & Area & \\
square mile $\left(\mathrm{mi}^{2}\right)$ & 259.0 & hectare $($ ha) \\
\hline & 2.590 & square kilometer $\left(\mathrm{km}^{2}\right)$ \\
\hline cubic foot per second $\left(\mathrm{ft}^{3} / \mathrm{s}\right.$ or cfs) & Flow rate & \\
\hline
\end{tabular}

Vertical coordinate information is referenced to the North American Vertical Datum of 1988 (NAVD 88).

\section{Abbreviations}

$\begin{array}{ll}+/- & \text { Plus or minus } \\ \% & \text { Percent } \\ 7010 & \text { 7-day annual minimum discharge with 10-year return period } \\ \text { Addison.Ck } & \text { Addison Creek at Bellwood, Illinois } \\ \text { Ck } & \text { Creek } \\ \text { CY } & \text { Calendar year } \\ \text { DPR } & \text { Des Plaines River } \\ \text { DPR.abvSalt.DAadj } & \text { Des Plaines River above Salt Creek with adjustment of } \\ \text { discharge for ungaged drainage area }\end{array}$




\begin{tabular}{|c|c|}
\hline IDNR & Illinois Department of Natural Resources \\
\hline ISWS & Illinois State Water Survey \\
\hline MWRD & Metropolitan Water Reclamation District of Greater Chicago \\
\hline N/A & Not available \\
\hline OLS & Ordinary least squares \\
\hline OWR & Office of Water Resources \\
\hline 07 & 7-day annual minimum discharge \\
\hline SaltCk.at.div.DAadj & $\begin{array}{l}\text { Salt Creek at diversion with adjustment of discharge for } \\
\text { ungaged drainage area }\end{array}$ \\
\hline SaltCk.at.div.noDAadj & $\begin{array}{l}\text { Salt Creek at diversion without adjustment of discharge for } \\
\text { ungaged drainage area }\end{array}$ \\
\hline SaltCk.MWRDdiv.DAadj & $\begin{array}{l}\text { Salt Creek diversion computed with MWRD rating with } \\
\text { adjustment of discharge of Salt Creek at diversion for } \\
\text { ungaged drainage area }\end{array}$ \\
\hline SaltCk.MWRDdiv.noDAadj & $\begin{array}{l}\text { Salt Creek diversion computed with MWRD rating without } \\
\text { adjustment of discharge of Salt Creek at diversion for } \\
\text { ungaged drainage area }\end{array}$ \\
\hline SaltCk.WSprings & Salt Creek at Western Springs, Illinois. \\
\hline USACE & U.S. Army Corps of Engineers \\
\hline WWTP & Wastewater Treatment Plant \\
\hline WY & Water year \\
\hline
\end{tabular}




\title{
Independent Technical Review and Analysis of Hydraulic Modeling and Hydrology Under Low-Flow Conditions of the Des Plaines River Near Riverside, Illinois
}

\author{
By Thomas M. Over, Timothy D. Straub, Jon E. Hortness, and Elizabeth A. Murphy
}

\section{Introduction}

The U.S. Geological Survey (USGS) has operated a streamgage and published daily flows for the Des Plaines River at Riverside since Oct. 1, 1943. A HEC-RAS model has been developed to estimate the effect of the removal of Hofmann Dam near the gage on low-flow elevations in the reach approximately 3 miles upstream from the dam. The Village of Riverside, the Illinois Department of Natural Resources-Office of Water Resources (IDNR-OWR), and the U. S. Army Corps of Engineers-Chicago District (USACE-Chicago) are interested in verifying the performance of the HEC-RAS model for specific low-flow conditions, and obtaining an estimate of selected daily flow quantiles and other low-flow statistics for a selected period of record that best represents current hydrologic conditions. Because the USGS publishes streamflow records for the Des Plaines River system and provides unbiased analyses of flows and stream hydraulic characteristics, the USGS served as an Independent Technical Reviewer (ITR) for this study. 


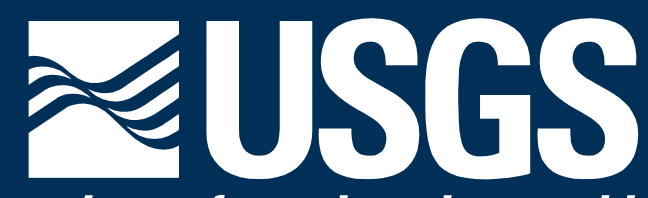

science for a changing world

\section{Independent Technical Review} and Analysis of Hydraulic Modeling and Hydrology Under Low-Flow Conditions of the Des Plaines River Near Riverside, Illinois 


\section{Background}

- Hofmann Dam

- Low-head dam on the Des Plaines River in Riverside

- Constructed by the State of Illinois in 1950

- The U. S. Army Corps of Engineers - Chicago District (USACE) has developed plans to remove the dam.

- HEC-RAS model

- Developed by the U. S. Army Corps of Engineers Chicago District

- Model the effects of the removal of Hofmann Dam

- Study area is Hofmann Dam to $26^{\text {th }}$ Street (approximately $3 \mathrm{mi}$ ) 
What is the USGS?

- U.S. Geological Survey

- Department of Interior

- Nation's largest earth science agency

- No regulatory responsibility

- Created by Congress in 1879

- Mission

- Provide the Nation with reliable, impartial information about the Earth

- Data collection and interpretive projects 
Streamflow Data within Area of Detailed Study

- USGS streamflow-gaging station 05532500 on Des Plaines River

- Downstream of Hofmann Dam (Millbridge Road)

- Continuous streamflow data since 1943

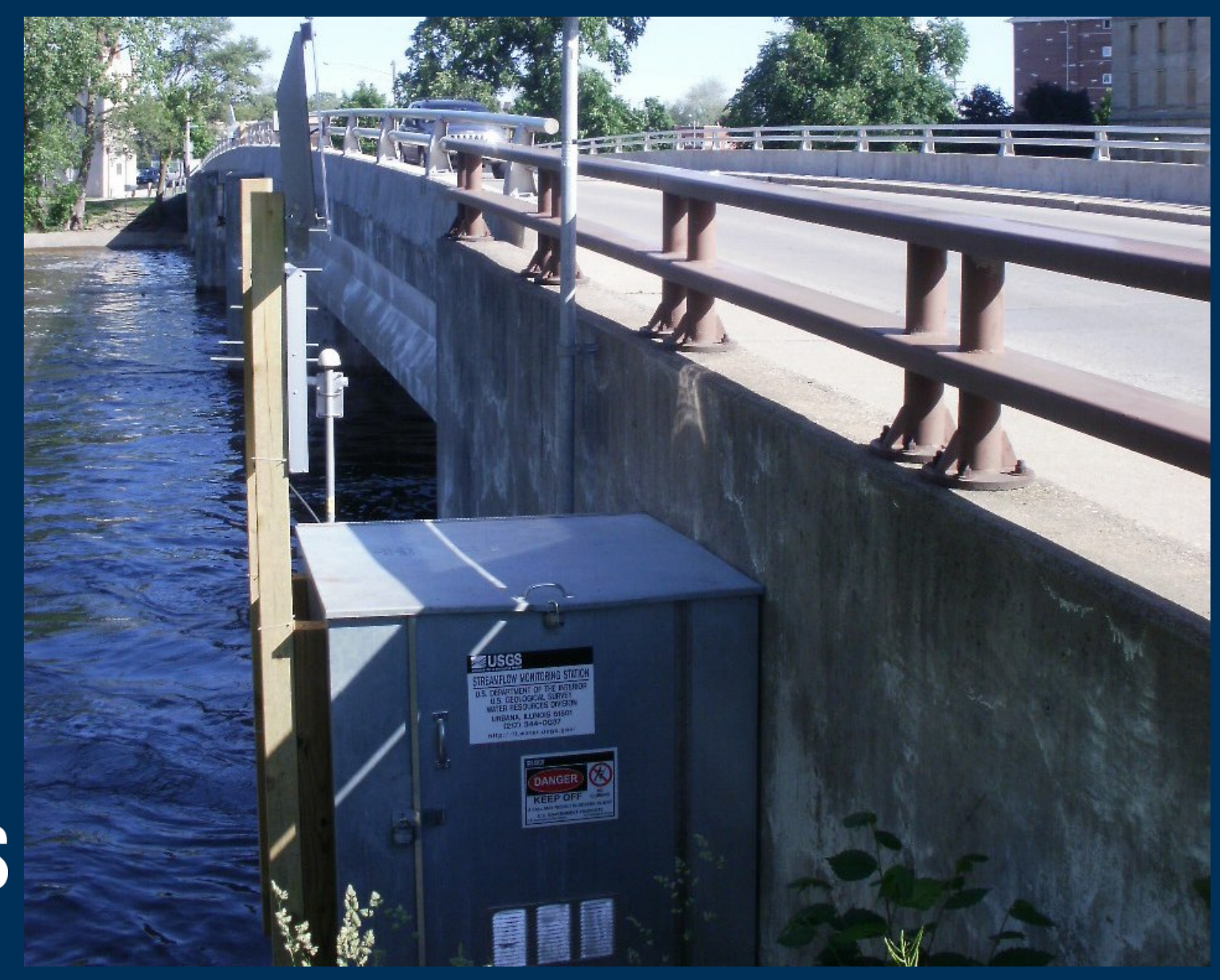


Components of the Technical Review/Analysis Under Low-Flow Conditions

- Field data collection

- Hydraulic model verification (using field data collected)

- Hydrology review/analysis

- Hydraulic model results (using flows determined in hydrologic analysis)

\section{¿USGS}




\section{Study Area Map}

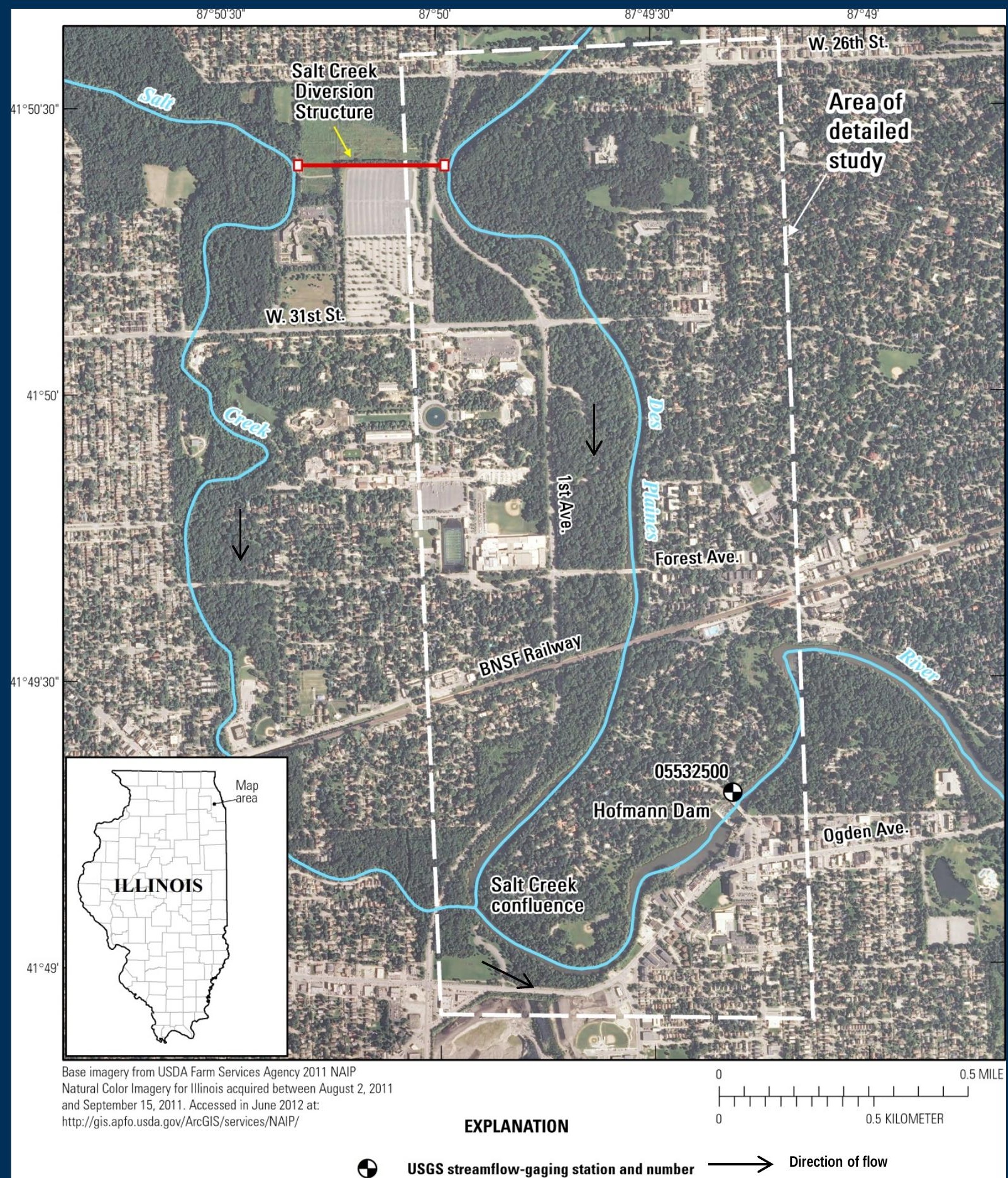




\section{Field Data Collection Under Low-Flow Conditions}

- Flow measurements

- Water-surface elevations

- Manning's Roughness observations 


\section{Salt Creek Diversion Structure}

- Constructed in 1960

- Inlet modified in 1967

- Main purpose: flood protection along Lower Salt Creek

- Flow in the diversion is controlled by the water level of Salt Creek

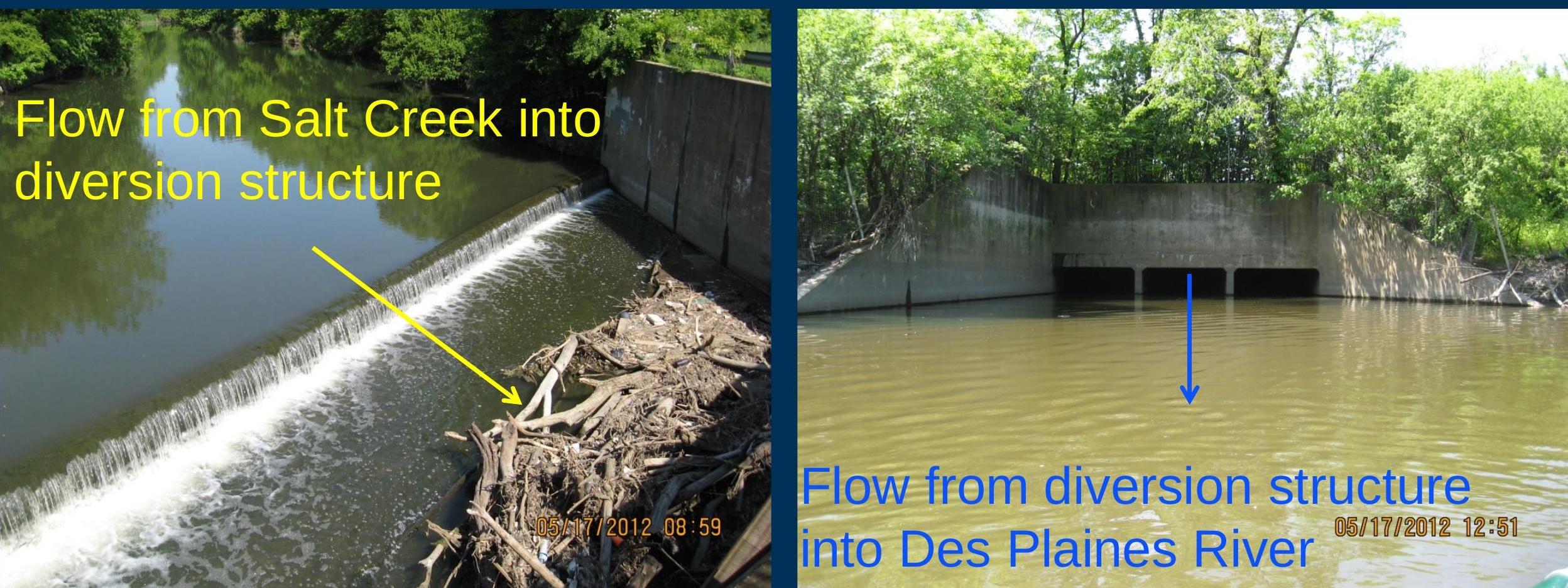




\section{Water-Surface}

\section{Elevations}

(May 17, 2012)

- GPS accuracy +l$0.07 \mathrm{ft}$

- Small errors possible due to difficulties holding equipment at water surface

- Computed drop in water surface between 26 $^{\text {th }}$ Street and Hofmann Dam was $0.92 \mathrm{ft}$

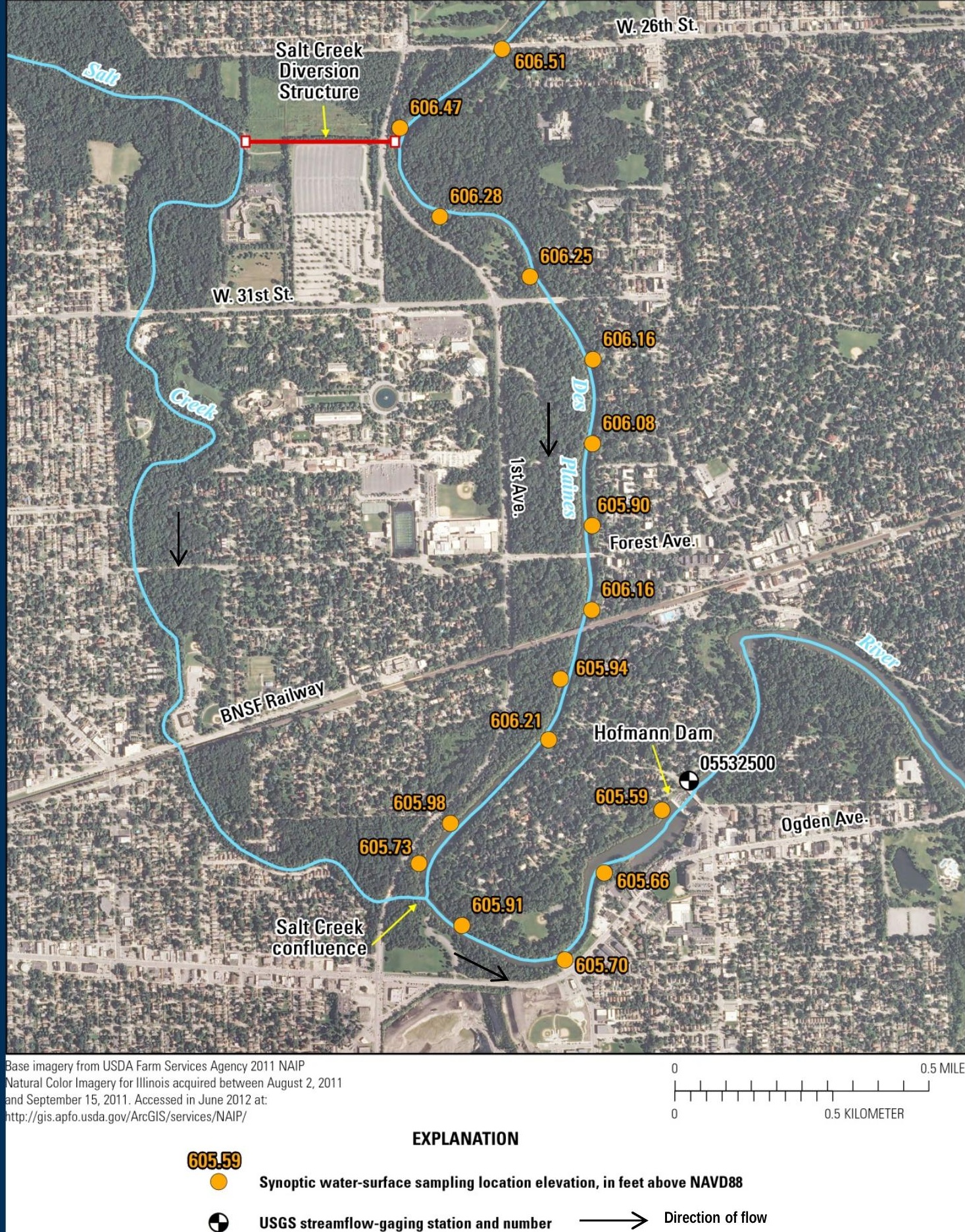




\section{Manning's Roughness (n-value)}

- A measure of flow resistance based on several factors including: channel material, channel shape, vegetation, etc.

- Used in hydraulic models to represent the resistance to flow in the channel

- Typical values in natural channels range from 0.025 to 0.070 (Chow, 1959) 
Manning's Roughness: Summary

- Manning's roughness in the study reach should likely range from approximately 0.035 to 0.045 .

- These values are relevant for flows within the main channel; values during flood conditions would be substantially different. 


\section{Hydraulic Model Verification}

- Comparison of modeled and observed water-surface elevations

- Manning's roughness sensitivity analysis 


\section{Observed Water}

\section{Surface}

Locations

and

Corresponding

Selected Model

Cross Sections

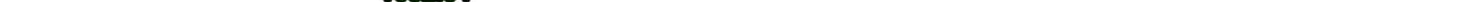




\section{Water Surface Elevations Modeled With Flows Measured on May 17, 2012}

\section{Manning's roughness $\mathbf{= 0 . 0 3 5}$}

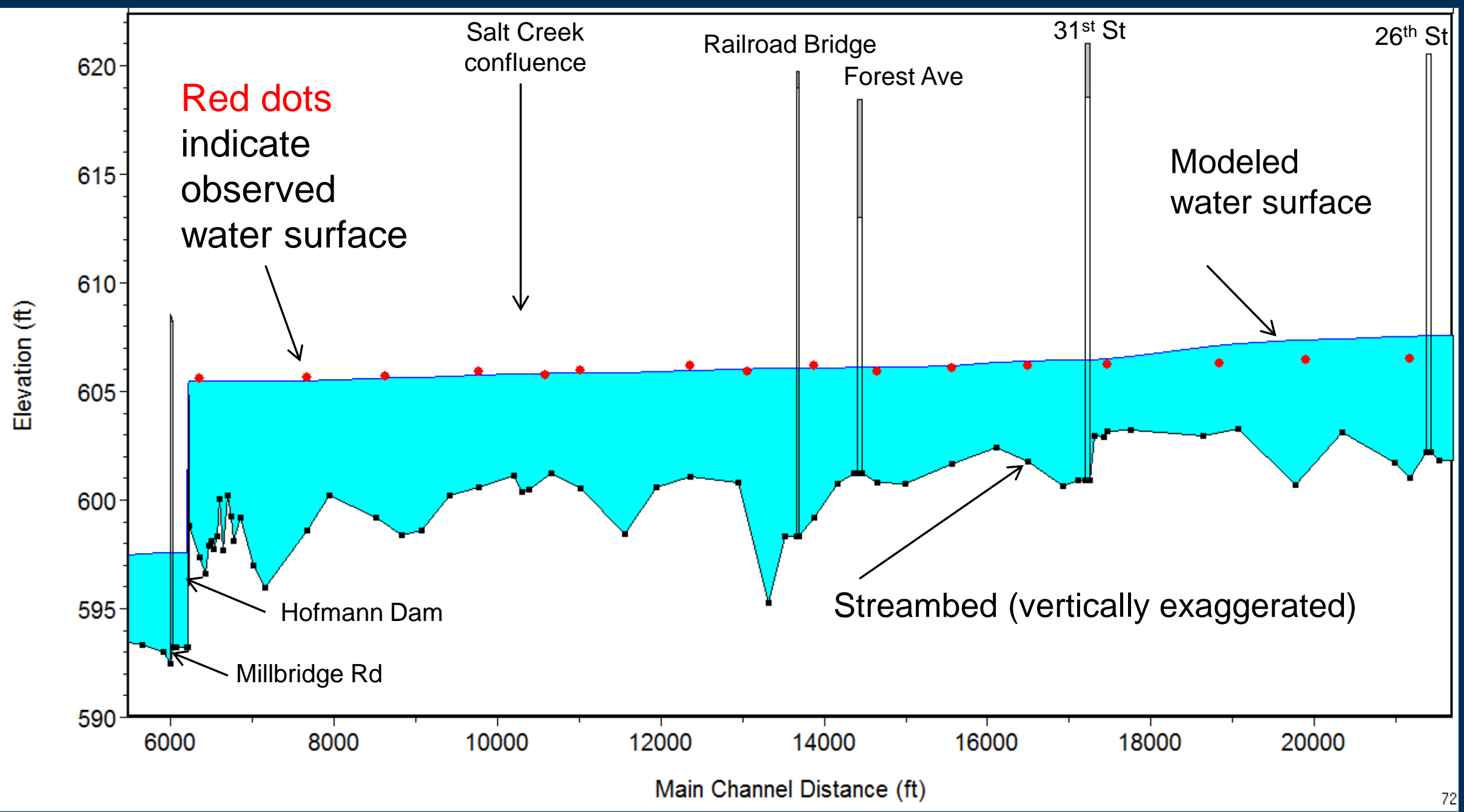




\section{Comparison Among Manning's Roughness Coefficients}

Main-channel Manning's roughness of $\mathbf{0 . 0 3 5}$ selected based on comparison of errors

\begin{tabular}{|c|c|}
\hline \multicolumn{2}{|c|}{ Dam to 31st Street } \\
\hline Manning's & \\
\hline Roughness & Error $^{1}$ \\
\hline Coefficient & (ft) \\
\hline 0.035 & $+/-0.16$ \\
\hline 0.040 & $+/-0.21$ \\
\hline 0.045 & $+/-0.30$ \\
\hline
\end{tabular}

${ }^{1}$ Root mean square error 


\section{Observed Flows Modeled}

Modeled with flows measured on May 17, 2012 Manning's roughness $=\mathbf{0 . 0 3 5}$

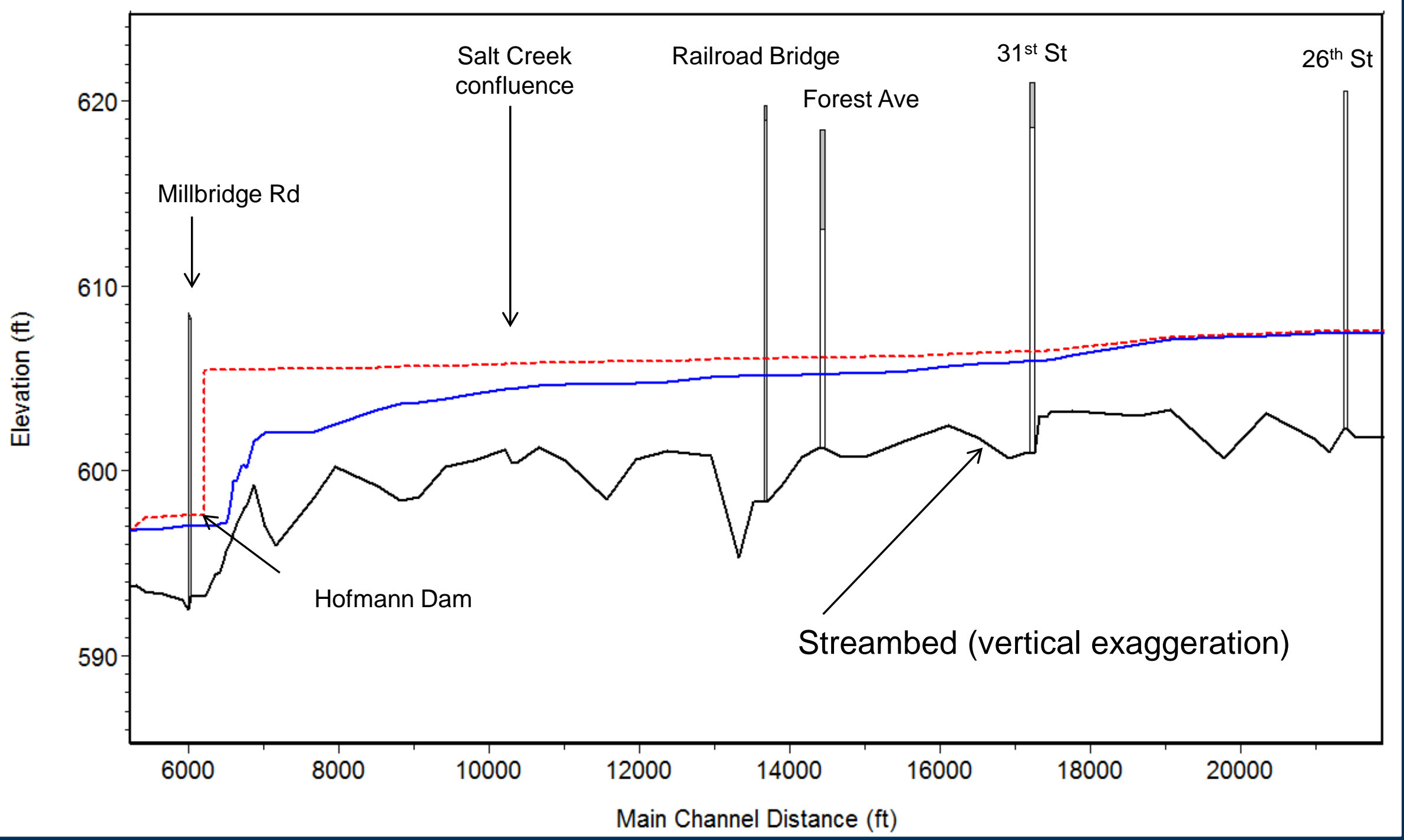




\section{Hydrology Review/Analysis}

- Purpose: Compute flow statistics for use in hydraulic modeling

- Overview of tasks

- Computation of daily flows

- Trend analyses of flow statistics to determine appropriate period of record

- Computation of flow statistics 
Flow Statistics Computed

- Daily flows with $\mathbf{8 0} \%$ (low), $\mathbf{5 0 \%}$, and $\mathbf{2 0 \%}$ exceedance probabilities

- 7Q10: annual 7-day minimum flow (Q7) with 10-year return period

$\triangle$ Only low flows results will be presented: $80 \%$ exceedance daily flow and 7Q10 


\section{Streamflow-} gaging Stations and Des Plaines River Study Reaches

Beginning of complete water years (WY) of published daily streamflow record:

05531500: 10-1-1945 05532000: 10-1-1951 05532500: 10-1-1943

Note:

132 of $150 \mathrm{mi}^{2}(88 \%)$ of Salt Creek watershed is gaged.

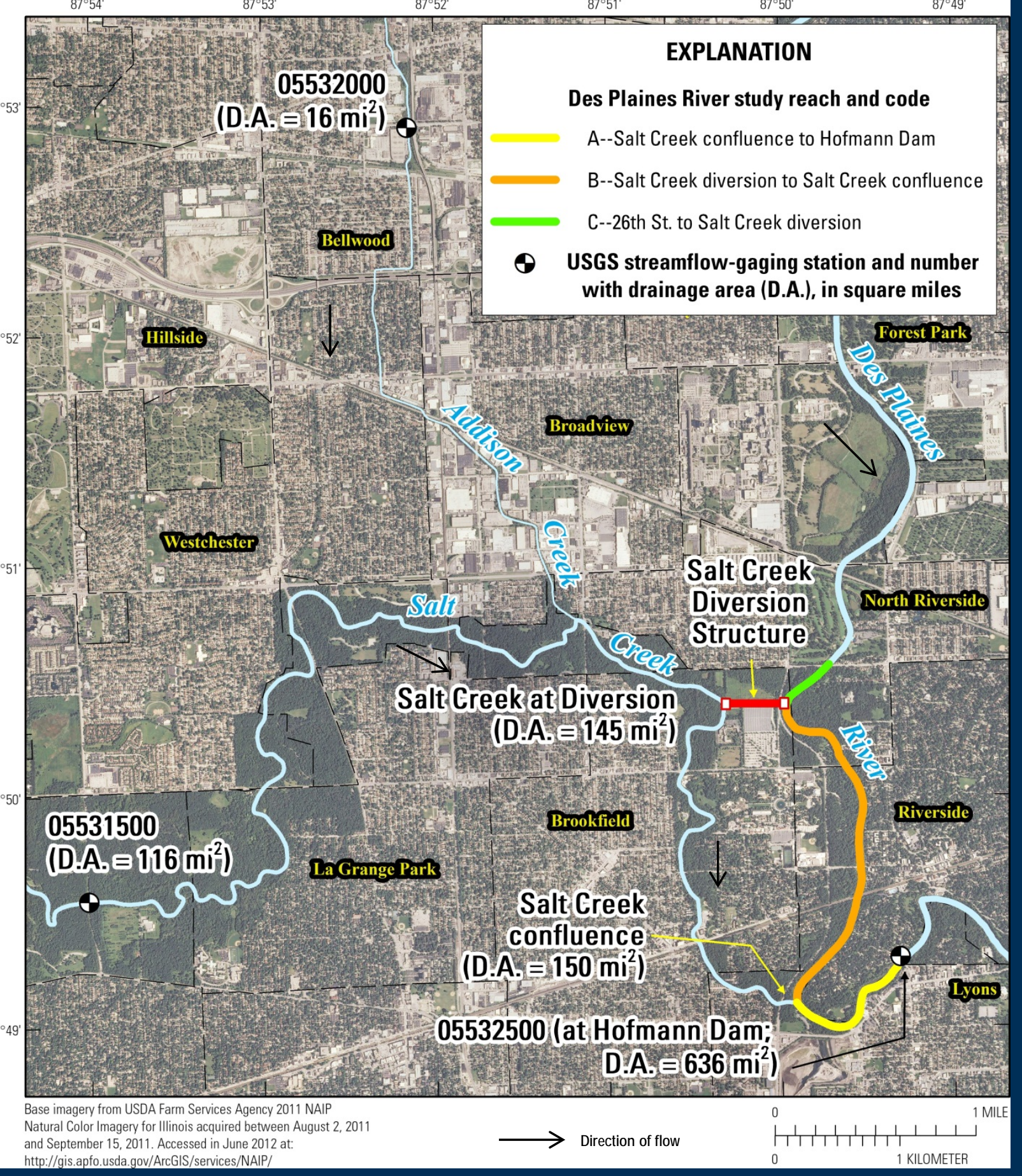




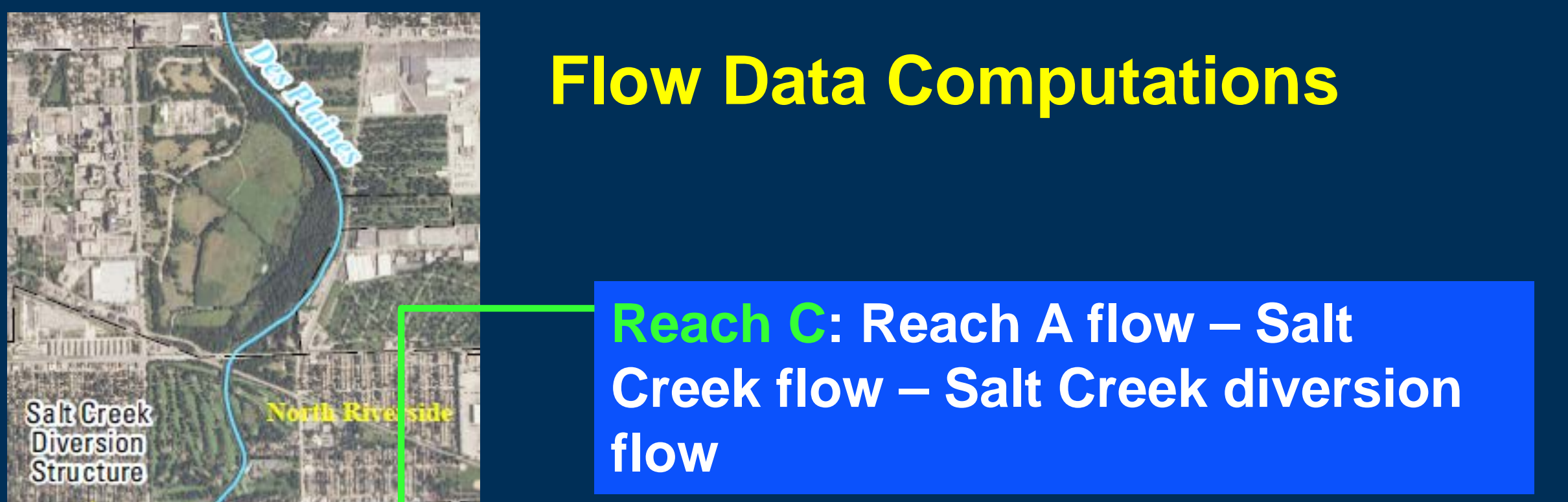

\section{Reach B: Reach A flow - Salt Creek flow}
Reach A: Flow measurements from gage near Hofmann Dam




\section{Salt Creek Diversion Ratings}

Notice major disagreement at low flows:

- OWR rating has $1 \mathrm{ft}^{3} / \mathrm{s}$ diverted at $700 \mathrm{ft}^{3} / \mathrm{s}$ in Salt Creek $=0.14 \% \sim 0$.

- MWRD rating has $1280 / 2850=44.9 \%$ diverted up to $2850 \mathrm{ft}^{3} / \mathrm{s}$ in Salt Creek.

- Our 5/17/12 measurement suggests low-flow rating is somewhere in the middle.

$>$ Because of this uncertainty, flows based on both ratings were computed, providing a range of possible values.

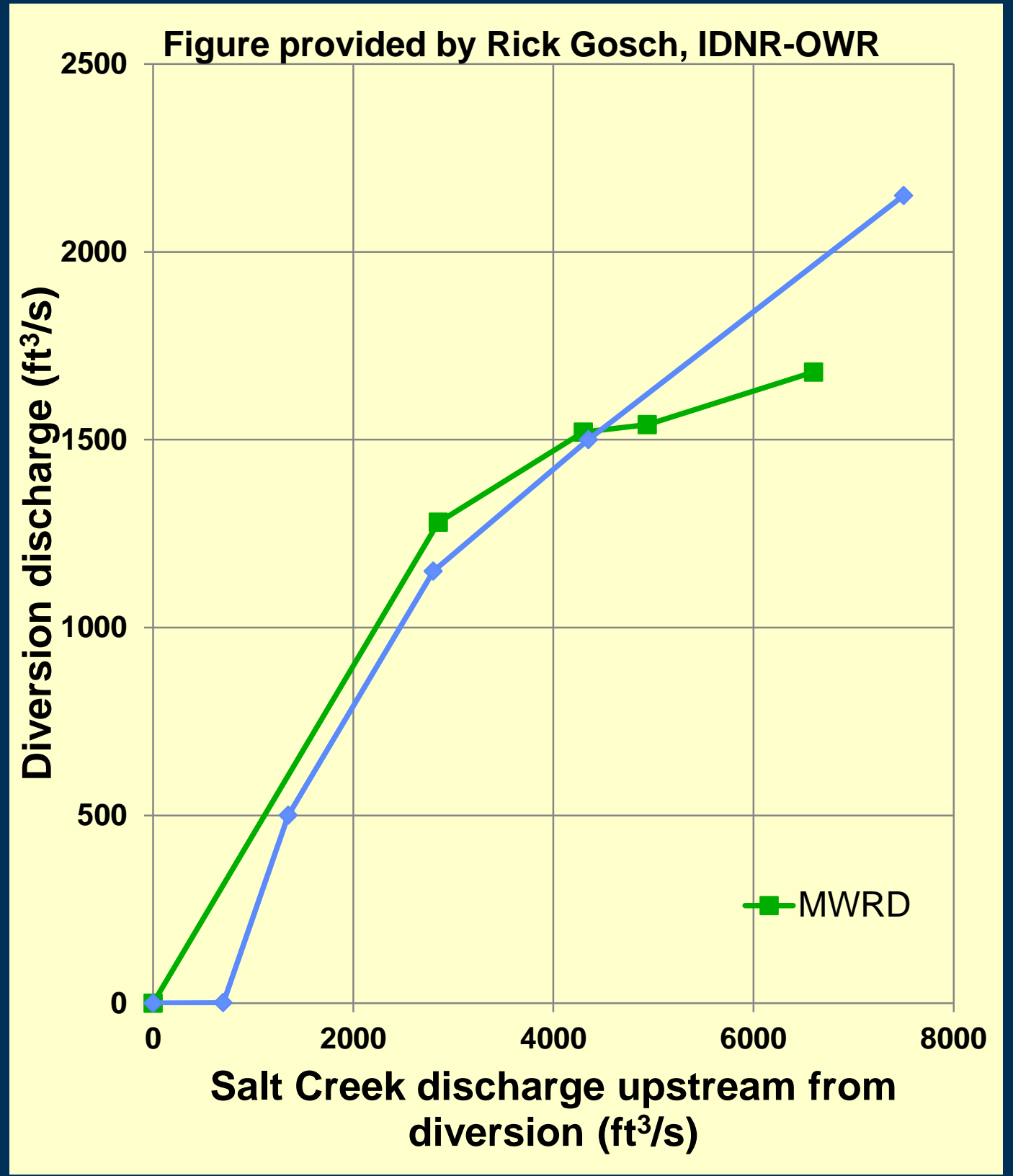




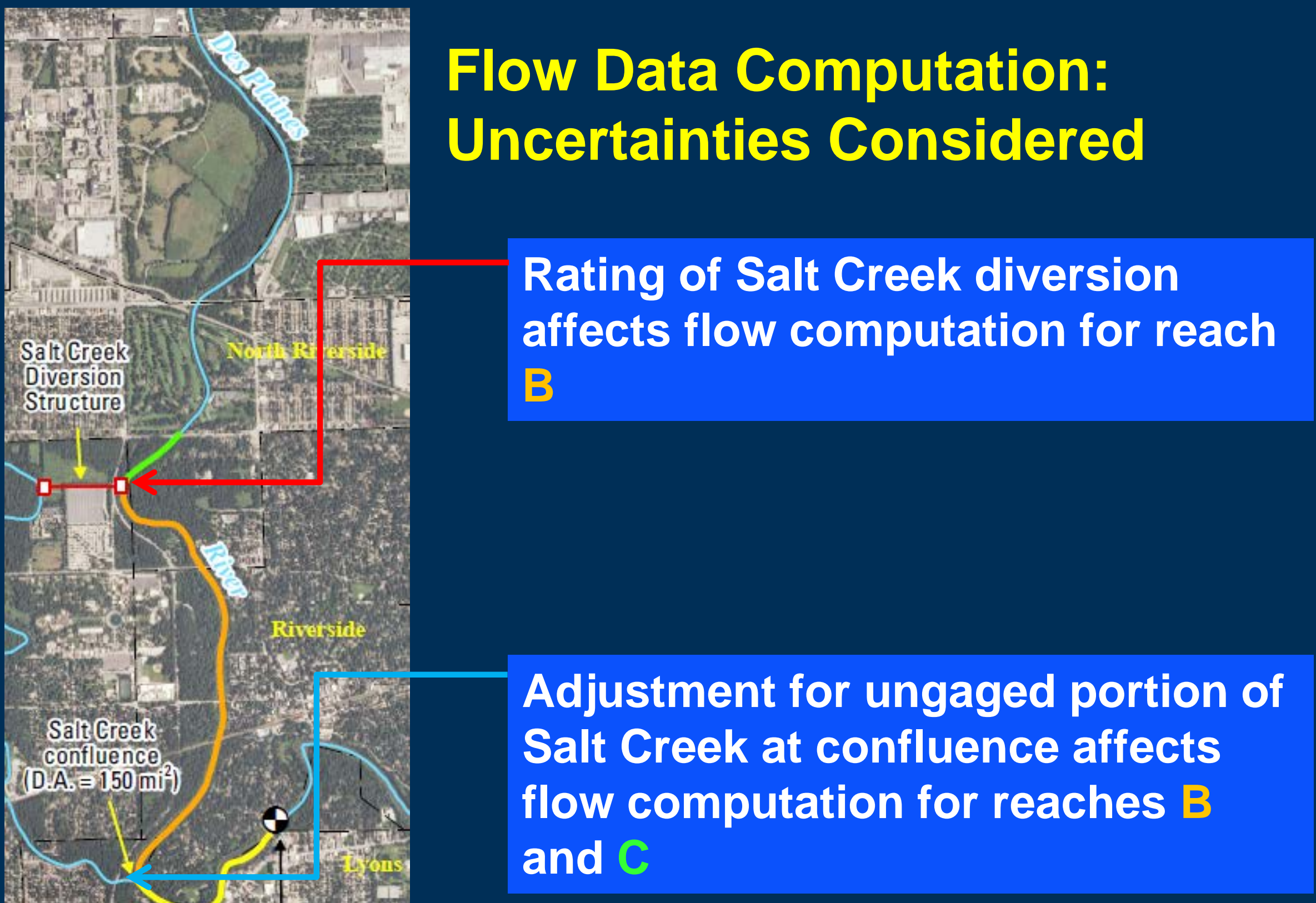


Trend Analysis of Annual Minimum 7-day Flow (Q7):

Conclusions

- Trended upward in the 1950 s and 1960 s and then jumped during the mid-to-late 1970s

- Trends since 1980 are small and not statistically different than zero

$>$ Estimate 7Q10 from 1980-2010 Q7 data 


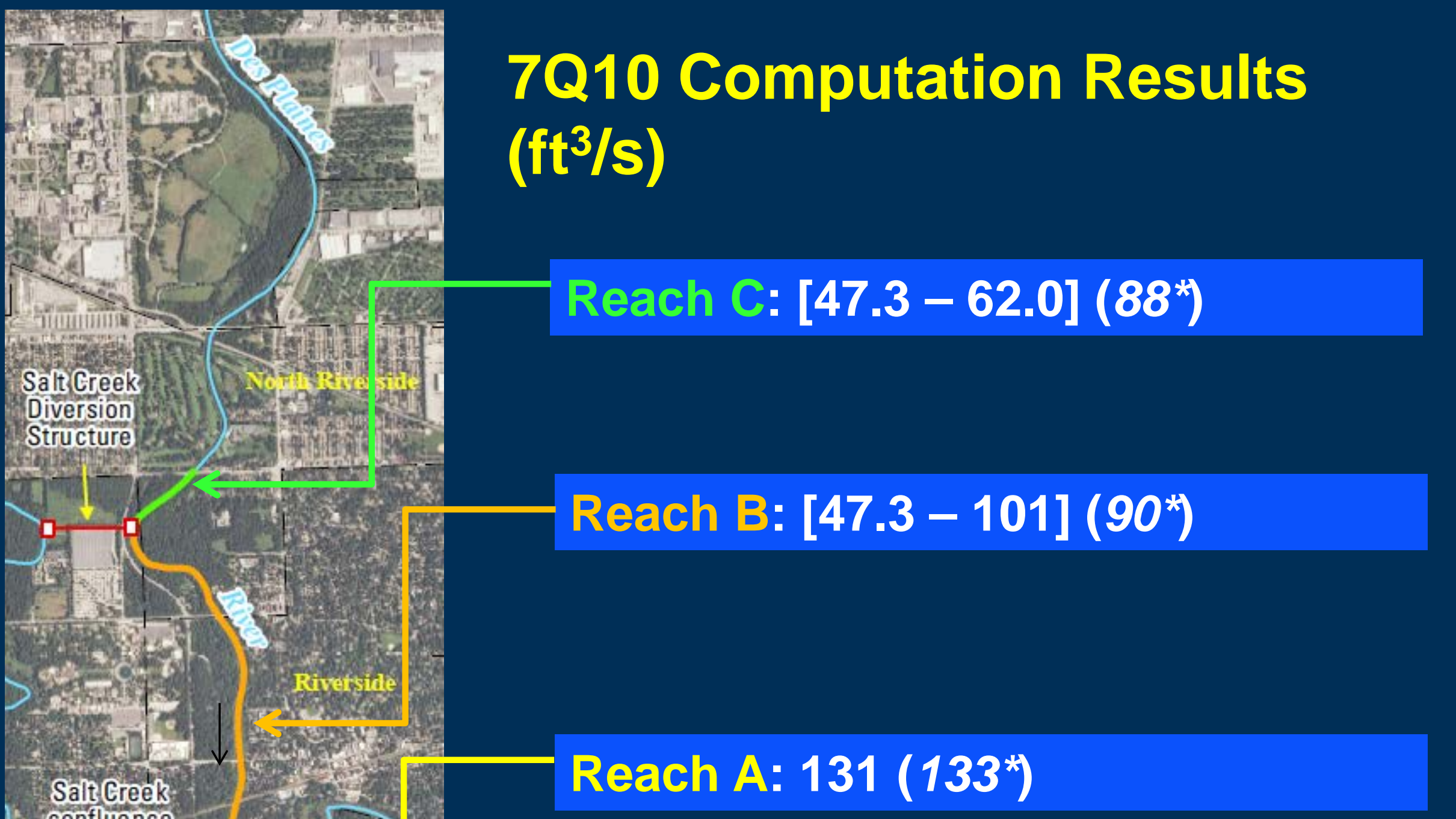

*Values in italics are from the Illinois State Water Survey (2003), included for comparison. 


\section{Trend Analysis of Annual Quantiles of $\mathbf{8 0 \%}$ Exceedance Daily Flow $\left(Q_{0.80}\right)$}

\section{Salt Ck at Western Springs (05531500)}

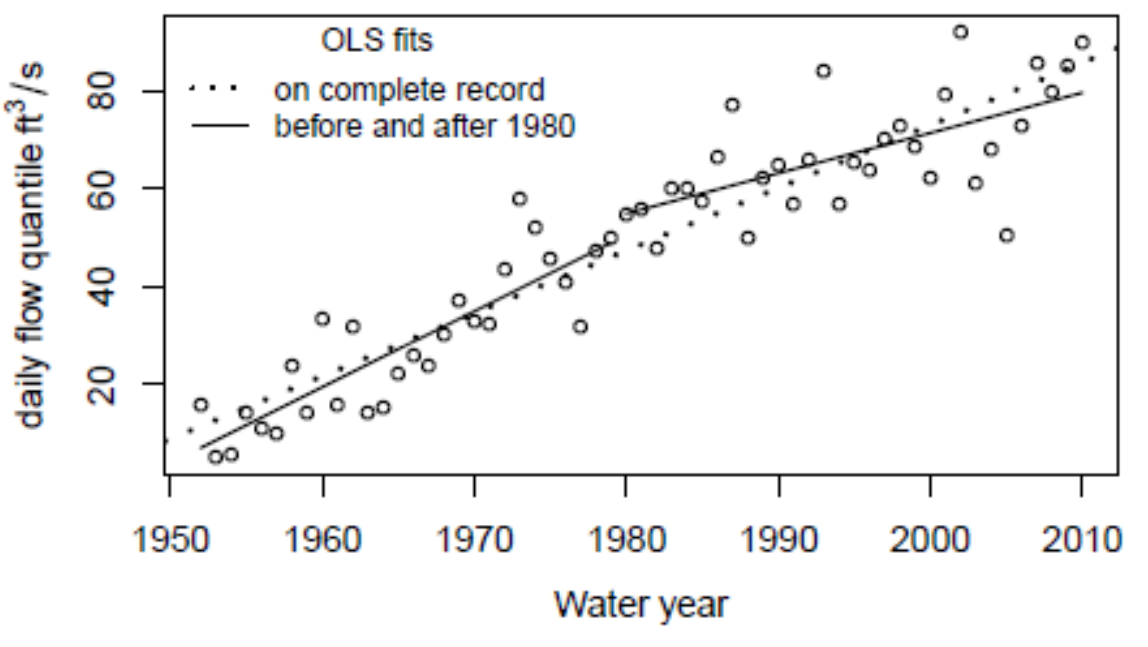

DPR above Salt Ck, adjusted for ungaged area

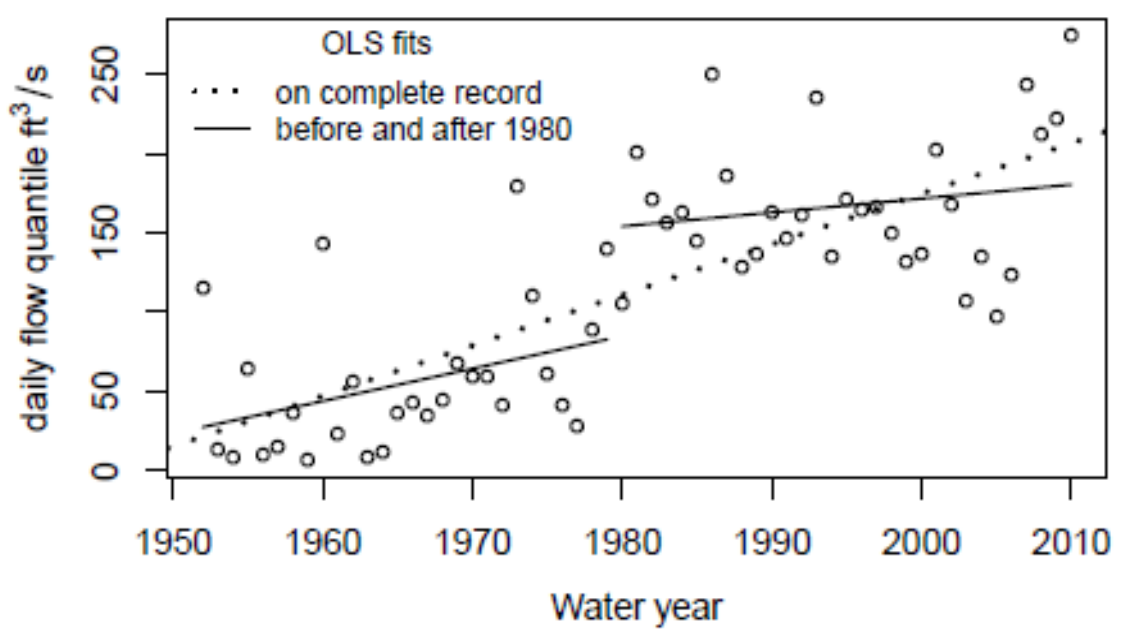

DPR at Riverside (05532500)

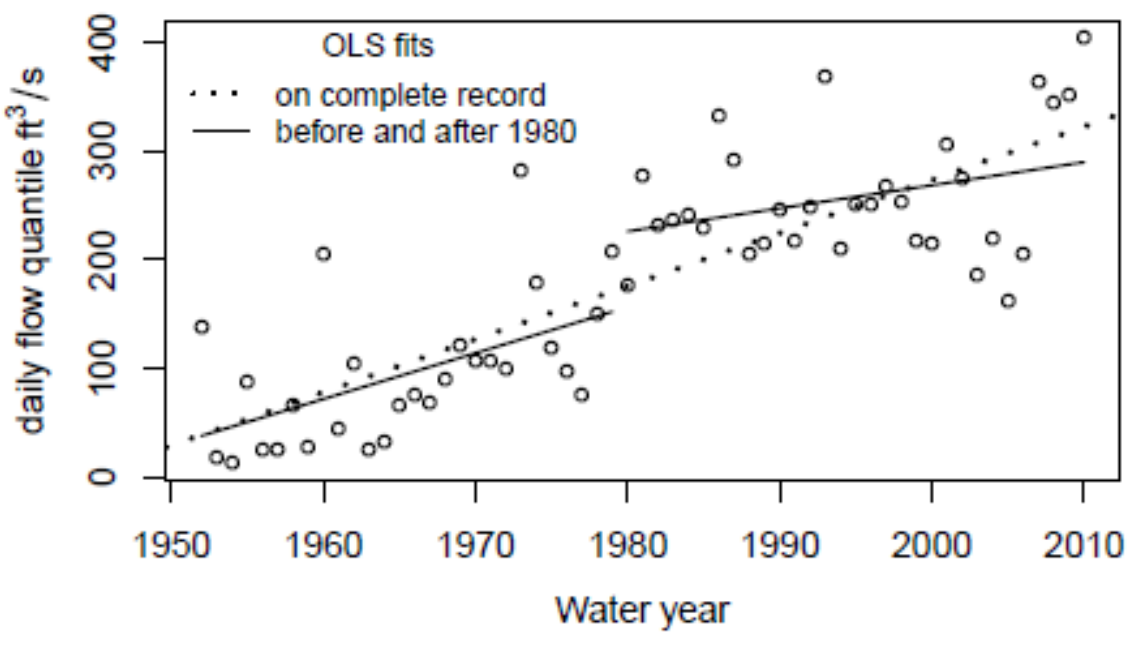

DPR above Salt Ck, MWRD diversion rating, adjusted for ungaged area

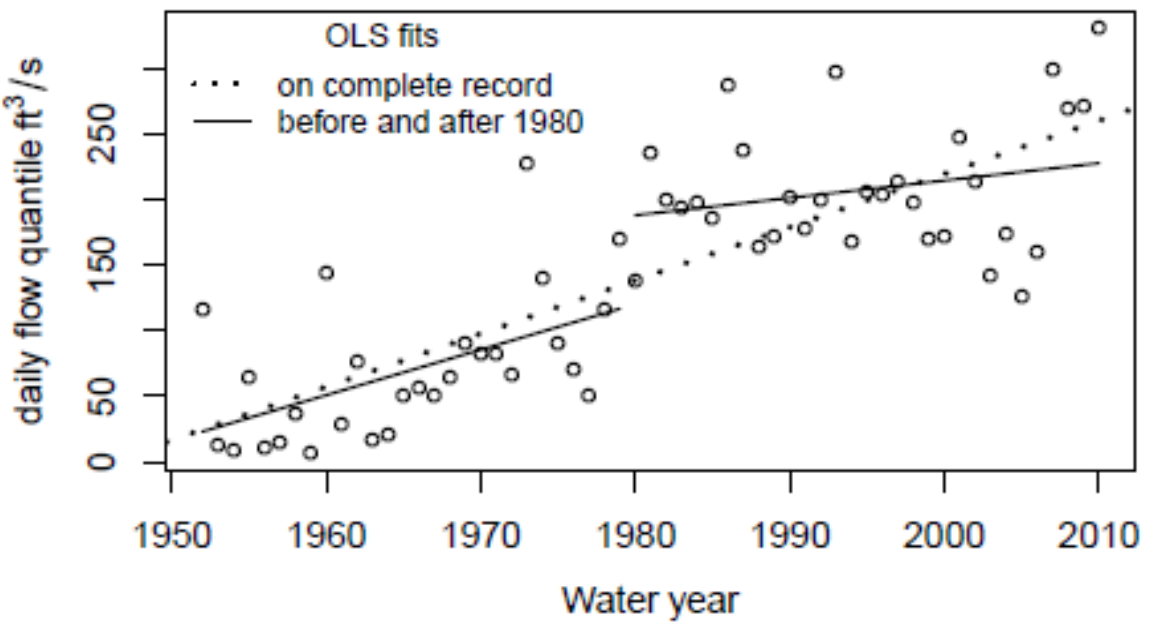


Trend Analysis of Daily Flow Quantiles: Conclusions

- Trends in quantiles of interest are generally positive throughout the period of record (1952-2010).

- As with the Q7 data, there is a break in the trend in mid-to-late 1970s.

- Unlike the Q7 data, trends since 1980 are positive.

$>$ Use data from $2000-2010^{1}$ to compute daily flow quantiles.

${ }^{1}$ This time period is a compromise between being recent and having enough data to estimate the flow value with reasonable accuracy. 


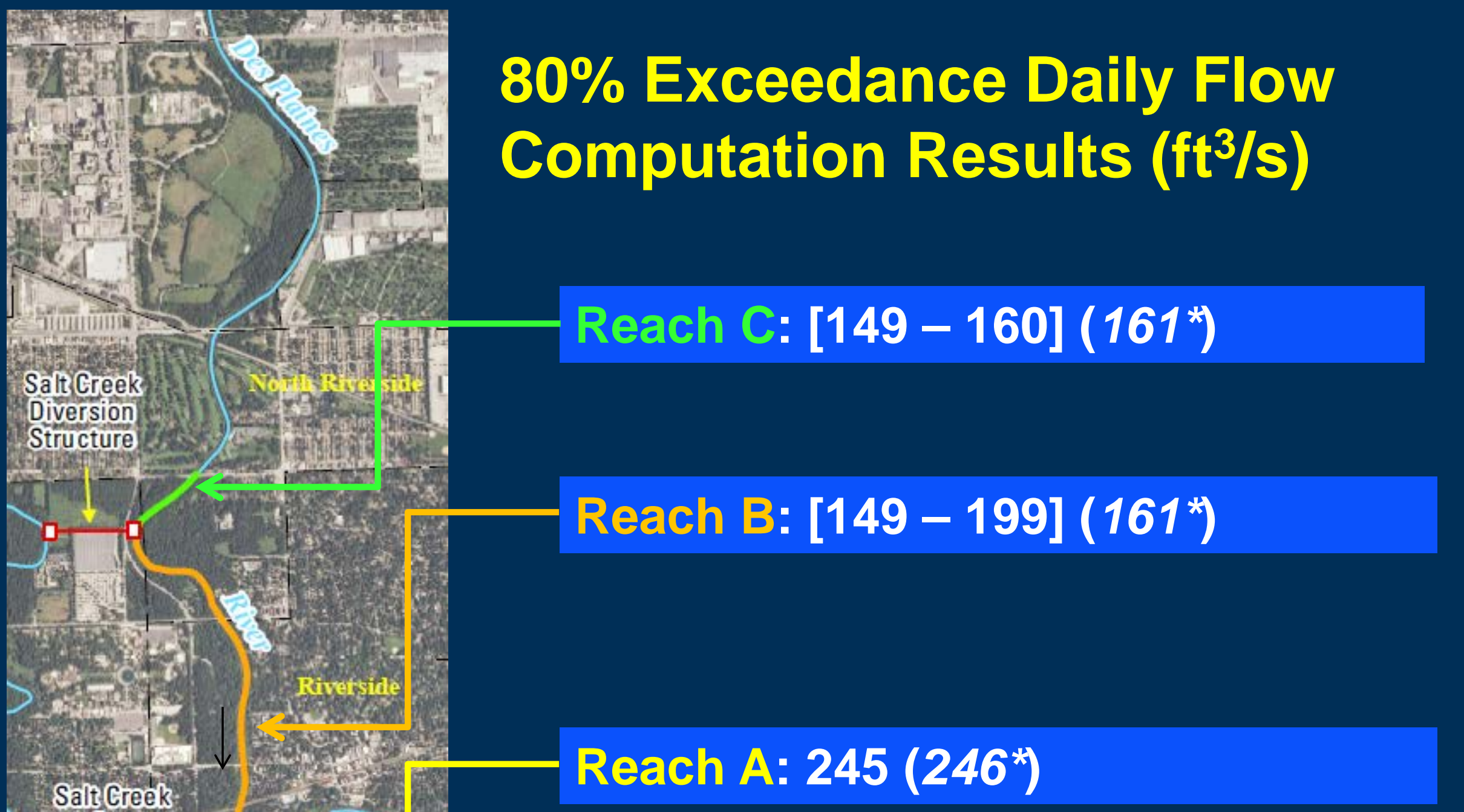

* Values in italics are from OWR presentation, Sept. 2011. 


\section{Hydraulic Model Results}

Water-surface elevations were modeled using:

- Manning's roughness of $\mathbf{0 . 0 3 5}$

- USGS computed flows (no diversion and diversion added)

Results are presented as:

- Longitudinal profiles (80\% exceedance and 7Q10)

- Cross section views (7Q10)

- Tables (80\% exceedance and 7Q10) 


\section{Conditions Modeled}

\section{- Hofmann Dam current conditions}

----- Existing (no diversion)

-.-.-. Existing (diversion added)

- 150-ft notch in Hofmann Dam

Proposed (no diversion) Proposed (diversion added) 


\section{Hydraulic Model Result Locations}

- 26 $6^{\text {th }}$ to $31^{\text {st }}$ Street

- 31st to Railroad Bridge

- Railroad Bridge to Salt Creek

- Salt Creek to Hofmann Dam

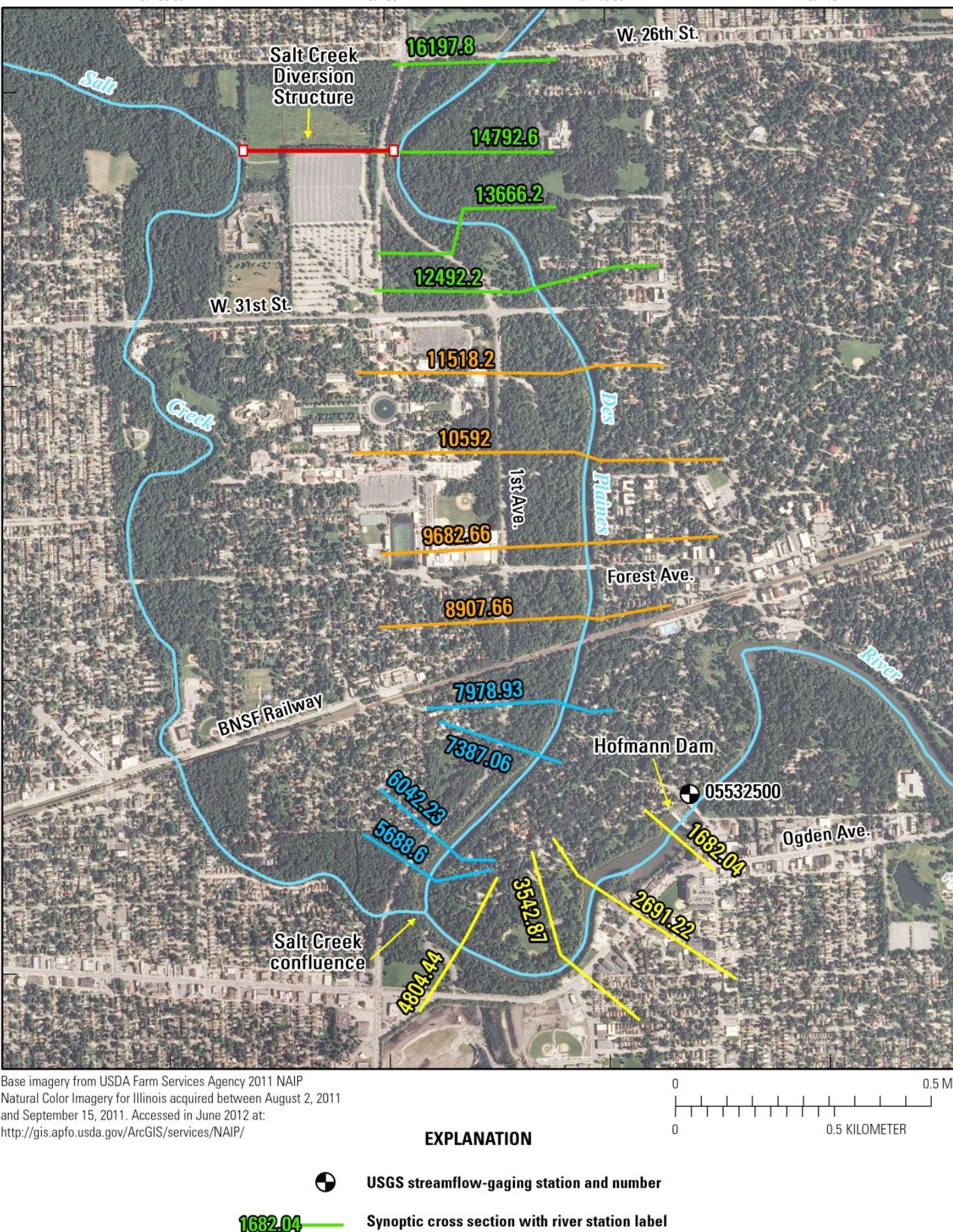




\section{Longitudinal Proffle 80\% Exceedance}

------- Existing (no diversion)

----m--- Existing (diversion added) Proposed (no diversion) Proposed (diversion added)

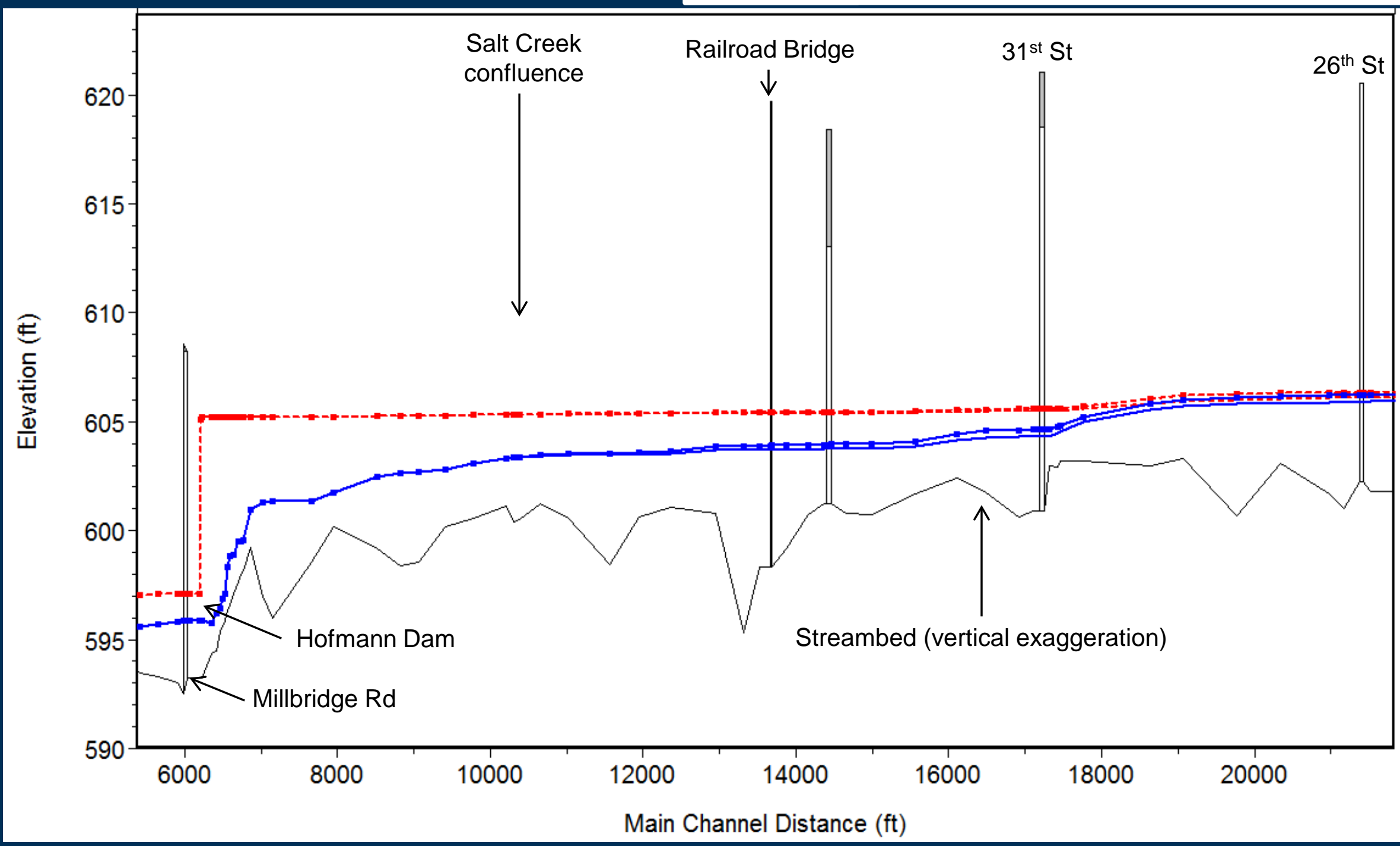




\section{Longitudinal Proffle 80\% Exceedance}

------ Existing (no diversion)

------- Existing (diversion added) Proposed (no diversion) Proposed (diversion added)

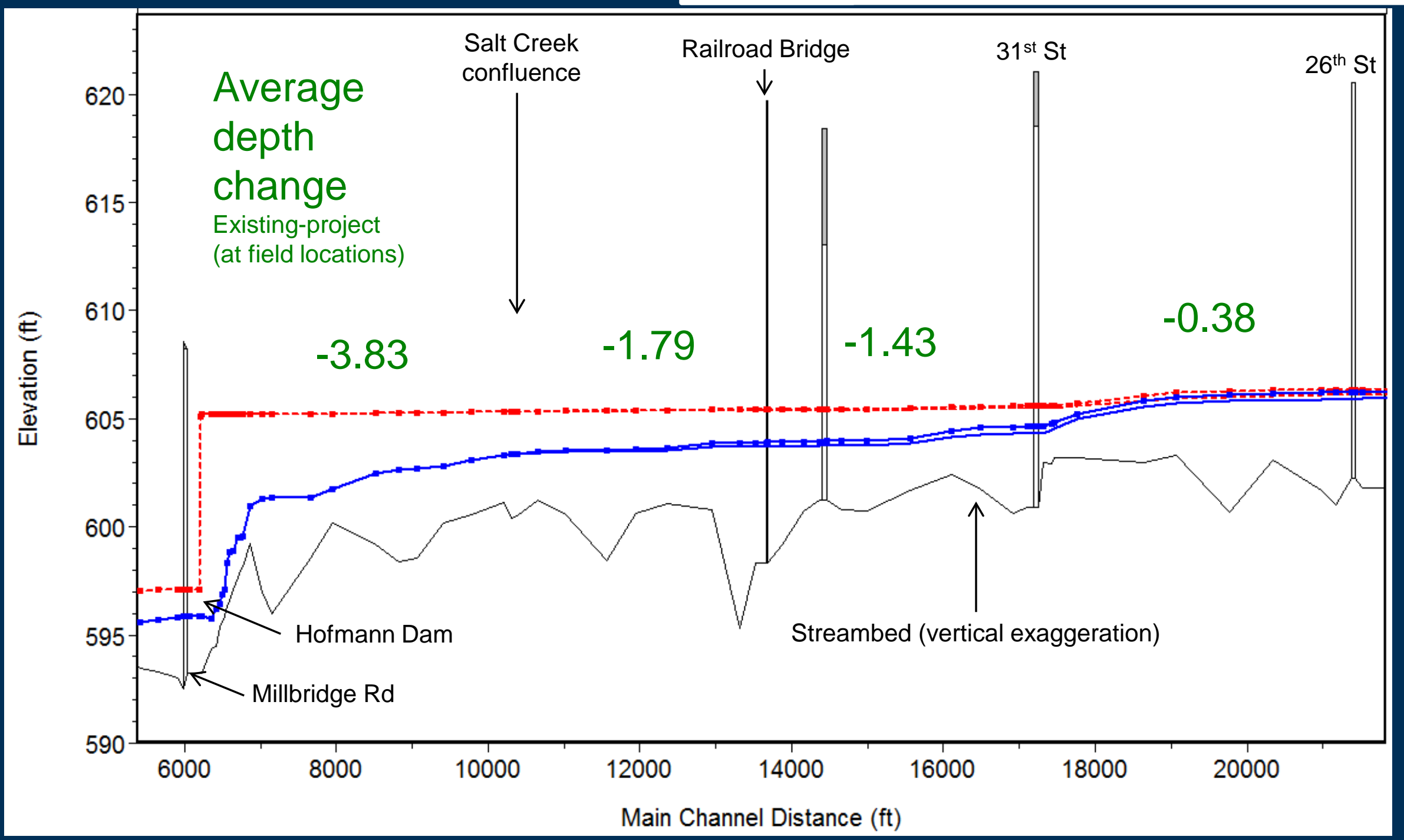




\section{Longitudinal Profile 7Q10}

------- Existing (no diversion)

------- Existing (diversion added)

Proposed (no diversion)

\section{Proposed (diversion added)}

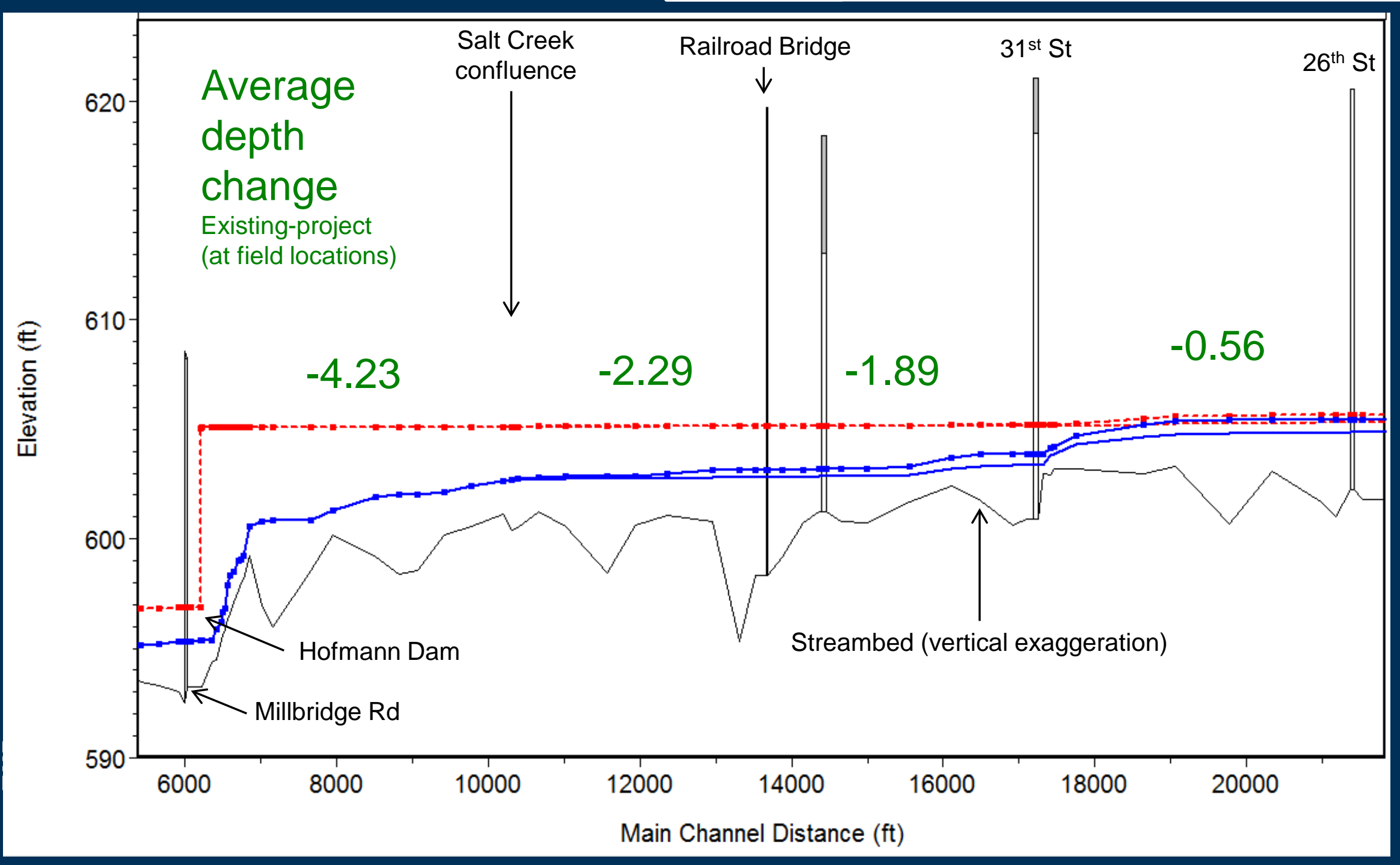




\section{Hydraulic Model Result Locations}

- 26 ${ }^{\text {th }}$ to $31^{\text {st }}$ Street

- $31^{\text {st }}$ to Railroad Bridge

- Railroad Bridge to Salt Creek

- Salt Creek to Hofmann Dam

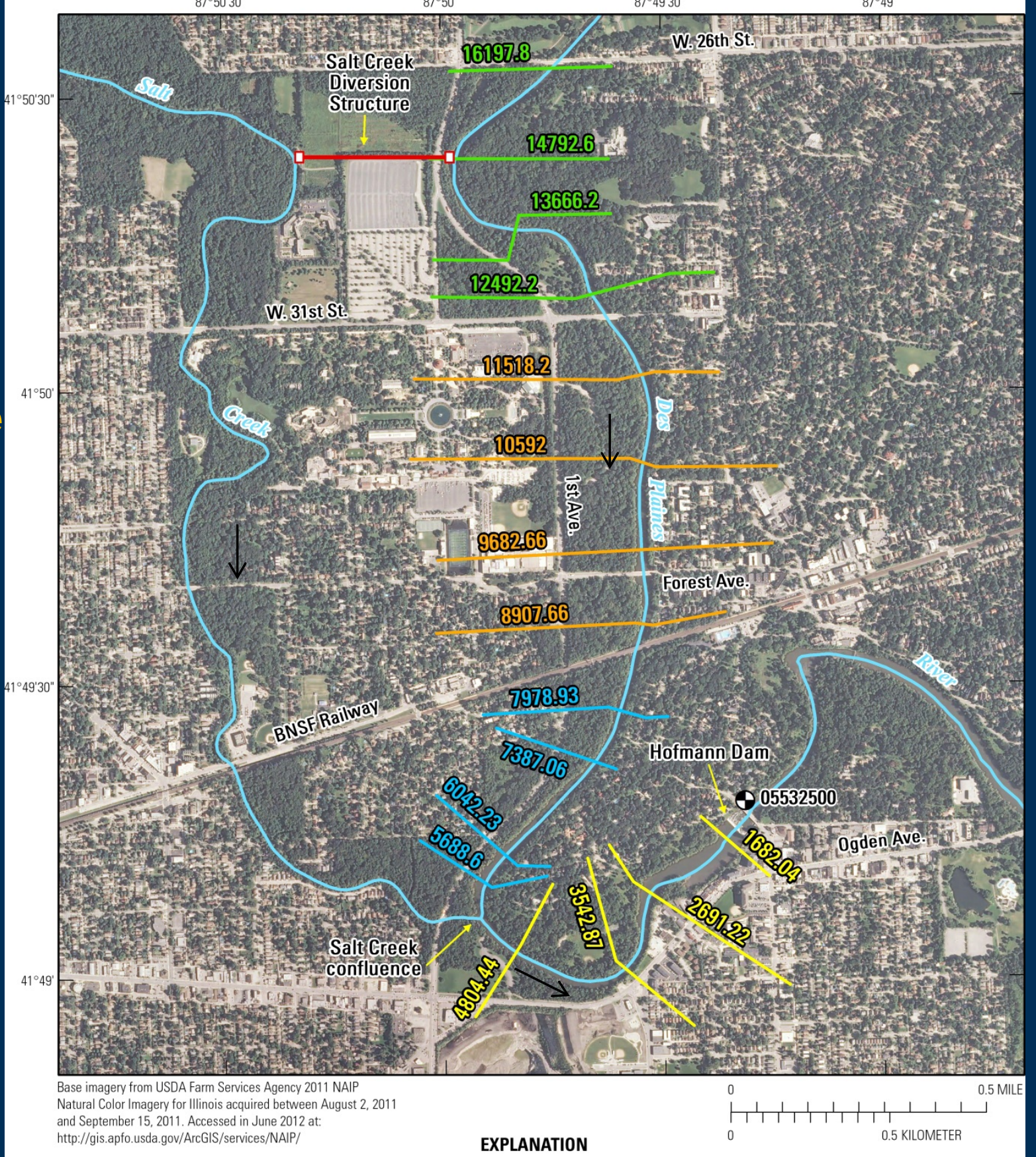

USGS streamflow-gaging station and number 


\section{Example Cross Section Plot and Line Legend}

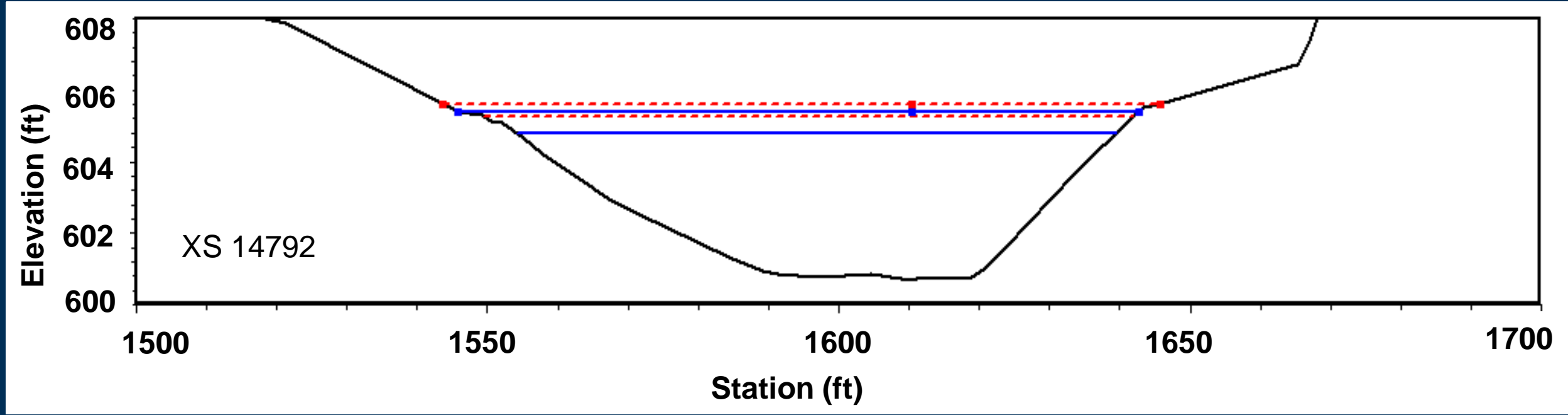

\#USGS

------ Existing (no diversion)

------ Existing (diversion added)

Proposed (no diversion)

- Proposed (diversion added) 


\section{Q10}

31 st Street

to

Railroad

Bridge

Average top width change = $-27.04 \mathrm{ft}$

Average maximum depth change = $-1.98 \mathrm{ft}$ \#USGS
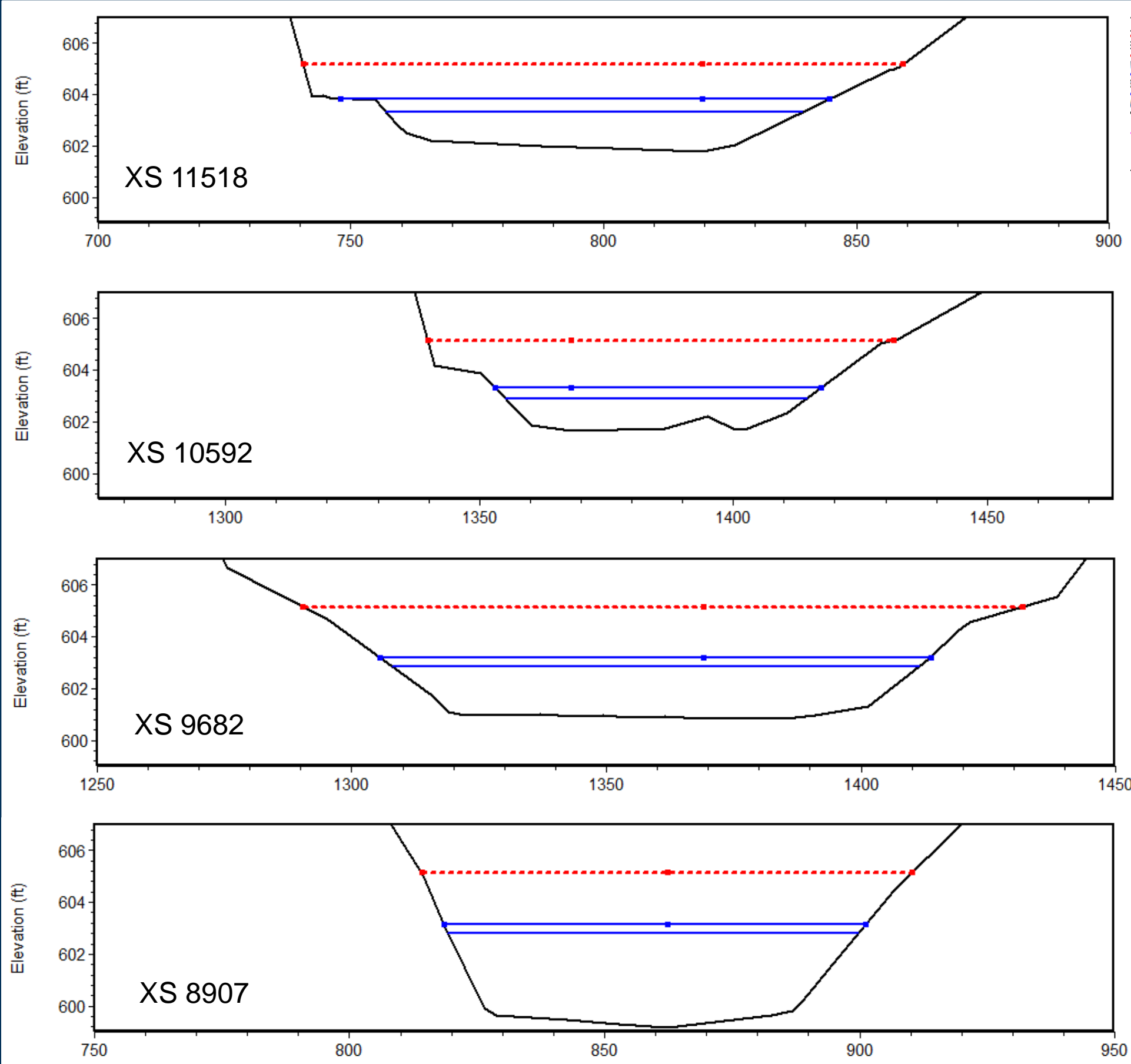


\section{$7 Q 10$}

\section{Railroad} Bridge to Salt Creek

Average top width change = $-46.57 \mathrm{ft}$

\section{Average} maximum depth change $=$ $-2.29 \mathrm{ft}$ \#USGS
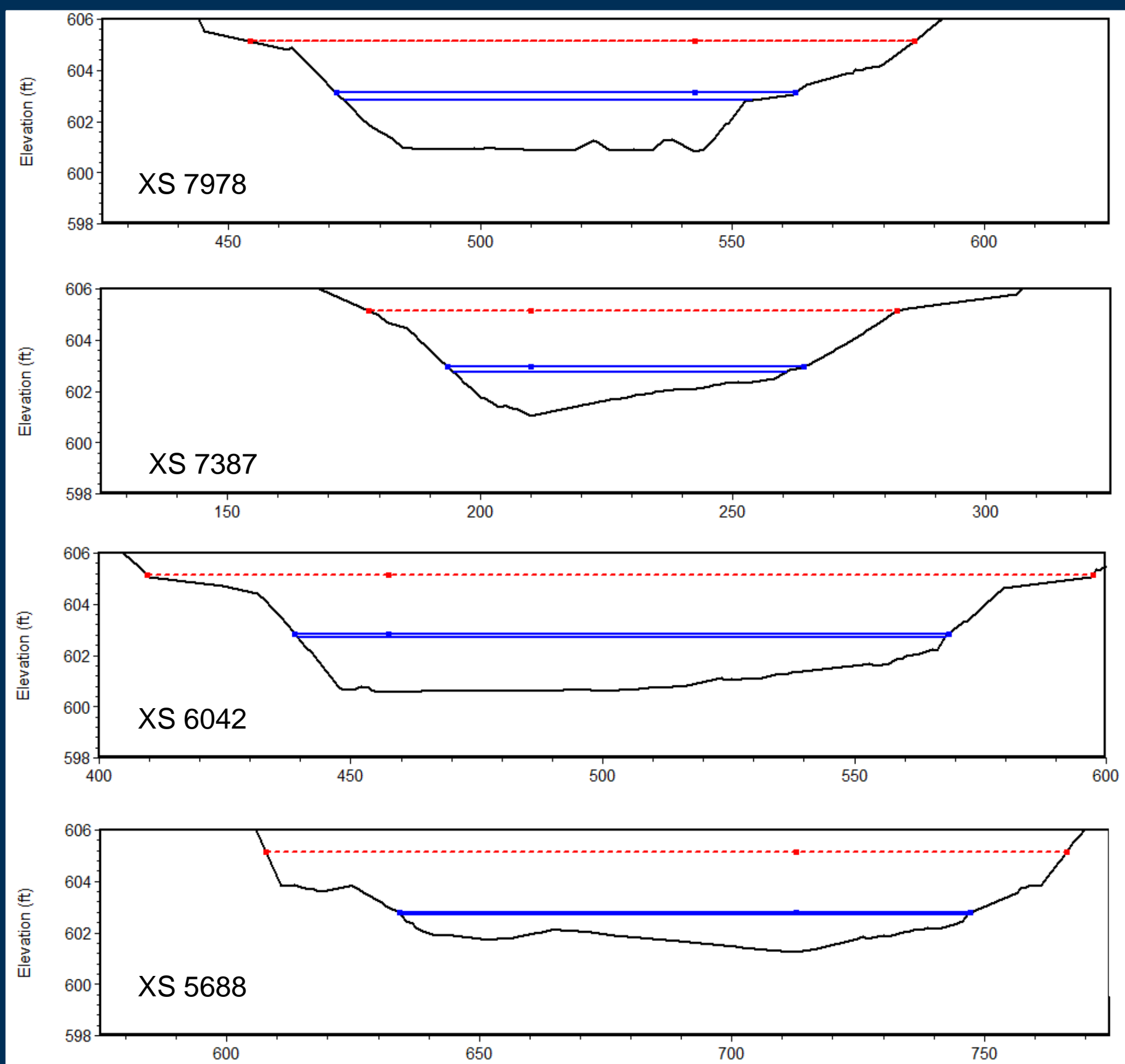


\section{Q10}

Salt Creek to Hofmann Dam

Average top width change $=$ $-123.11 \mathrm{ft}$

Average maximum depth change = $-4.23 \mathrm{ft}$ \#USGS
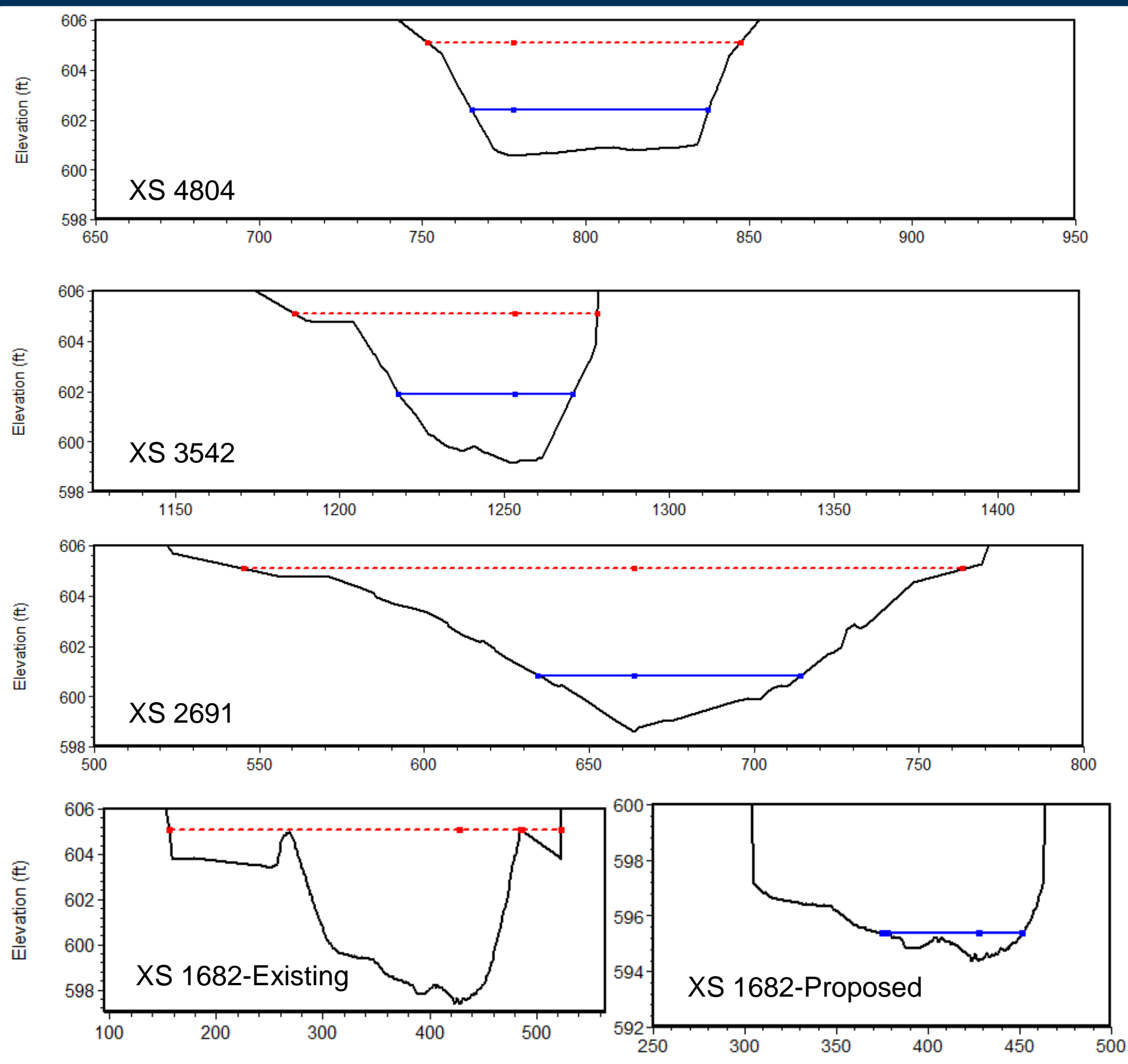


\section{Summary of USGS Activities}

\section{‡USGS}




\section{Summary of Field Data Collection}

- Data collected for model verification

- Flow measurements collected for model verification

- Water-surface elevations collected for model verification

- Field-estimated Manning's roughness ranged from 0.035 to 0.045

- Observed flow in Salt Creek diversion consistent with measured value 


\section{Summary of Model Verification}

- Hydraulic model verified from $31^{\text {st }}$ Street to Hofmann Dam

- Observed to modeled error $+\mid-0.16 \mathrm{ft}$ (for 0.035 Manning's roughness model)

- Manning's roughness of $\mathbf{0 . 0 3 5}$ selected

- The USACE model value was $\mathbf{0 . 0 4 0}$ (error $+1-0.21 \mathrm{ft}$ )

- Both values are within range of field estimations

\section{¿USGS}




\section{Summary of Hydrologic Analysis}

- Analysis of annual flow statistics indicated:

- Increasing flows in all statistics throughout 1950s-70s

- Use of flow data from 1980-2010 for annual 7-

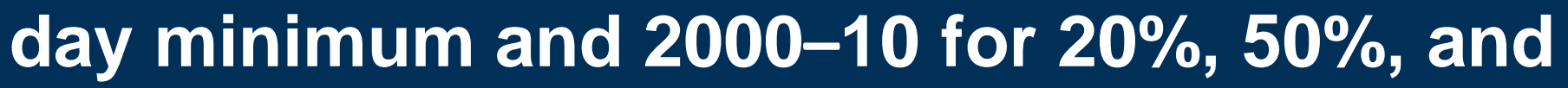
$80 \%$ exceedance daily flow quantiles

- Range of flow statistic values estimated for reaches above Salt Creek confluence depending on:

- diversion rating

- Salt Creek unmeasured drainage area

\section{¿USGS}




\section{Summary of Hydraulic Analysis: Change in Top Width}

- 16 cross sections total (four in each reach)

\begin{tabular}{|l|c|c|}
\hline \multirow{2}{*}{ Reach Location } & $\begin{array}{c}\text { 7Q10 Flows } \\
\text { (project minus existing) }\end{array}$ & $\begin{array}{c}\text { 80th Percentile Flows } \\
\text { (project minus existing) }\end{array}$ \\
\cline { 2 - 3 } & $\begin{array}{c}\text { Average Top Width } \\
\text { Change }(\mathrm{ft})\end{array}$ & $\begin{array}{c}\text { Average Top Width } \\
\text { Change }(\mathrm{ft})\end{array}$ \\
\hline 31st Street to 26th Street & -14.58 & -9.86 \\
Railroad to 31st Street & -27.04 & -19.00 \\
Salt Creek to Railroad & -46.57 & -39.30 \\
Hofmann Dam to Salt Creek & -123.11 & -116.09 \\
\hline
\end{tabular}




\section{Summary of Hydraulic Analysis: Change in Maximum Depth}

- 16 cross sections total (four in each reach)

\begin{tabular}{|l|c|c|}
\hline \multirow{2}{*}{ Reach Location } & $\begin{array}{c}\text { 7Q10 Flows } \\
\text { (project minus existing) }\end{array}$ & $\begin{array}{c}\text { 80th Percentile Flows } \\
\text { (project minus existing) }\end{array}$ \\
\cline { 2 - 3 } & $\begin{array}{c}\text { Average Maximum } \\
\text { Depth Change }(\mathrm{ft})\end{array}$ & $\begin{array}{c}\text { Average Maximum } \\
\text { Depth Change }(\mathrm{ft})\end{array}$ \\
\hline 31st Street to 26th Street & -0.56 & -0.38 \\
Railroad to 31st Street & -1.98 & -1.43 \\
Salt Creek to Railroad & -2.29 & -1.79 \\
Hofmann Dam to Salt Creek & -4.23 & -3.83 \\
\hline
\end{tabular}




\section{Hydrologic Analysis: \\ Additional Methods and Results Slides}

- Specific details on the methods and results of the hydrologic and hydraulic analyses are presented in the following slides including:

- Detailed information on hydrologic analysis methods and specific results for the $\mathbf{5 0}$ and 20 percentiles

- Detailed summary tables of all model results for the $\mathbf{8 0} \%, 50 \%$, and $20 \%$ exceedance daily flow quantiles and 7Q10 flow statistics

\section{₹USGS}




\section{Wastewater Treatment Plant Effluent Flows}

Table 2.2: Inflows above Station 05531500: Salt Creek at Western Springs

\begin{tabular}{|lrrrrrr|}
\hline & \multicolumn{7}{c|}{ Inflows $(c f s)$} \\
\cline { 2 - 7 } Source & 1940 & 1950 & 1960 & 1970 & 1980 & 1990 \\
& & & & & & \\
\hline John Egan Plant & - & - & - & - & 19.5 & 24.6 \\
Elk Grove Devon & - & - & - & - & 0.1 & - \\
Springbrook & - & 0.03 & 0.42 & 0.80 & 1.5 & 3.4 \\
Wood Dale & - & - & 0.36 & 1.1 & 1.7 & 2.0 \\
Addison & 0.08 & 0.08 & 0.88 & 3.8 & 5.5 & 5.9 \\
Salt Creek S. D. & 1.1 & 1.4 & 3.4 & 4.6 & 2.8 & 2.0 \\
Elmhurst & 1.9 & 2.6 & 4.8 & 7.3 & 10.4 & 6.5 \\
Oakbrook Terrace & - & - & - & 0.12 & - & - \\
Oak Brook & - & - & 0.09 & 1.6 & - & - \\
& & & & & & \\
\hline Total & 3.08 & 4.11 & 9.95 & 19.32 & 41.5 & 44.4 \\
& & & & & & \\
\hline
\end{tabular}

Table from Singh and Ramamurthy (1993)

Also note online information indicates MWRD Kirie WWTP, which discharges to Willow Creek. Kirie WWTP discharge enters the Des Plaines River below USGS streamflow-gaging station 0552900 but above the study area and began operation in 1980 . 


\section{ISWS 7Q10 Maps}
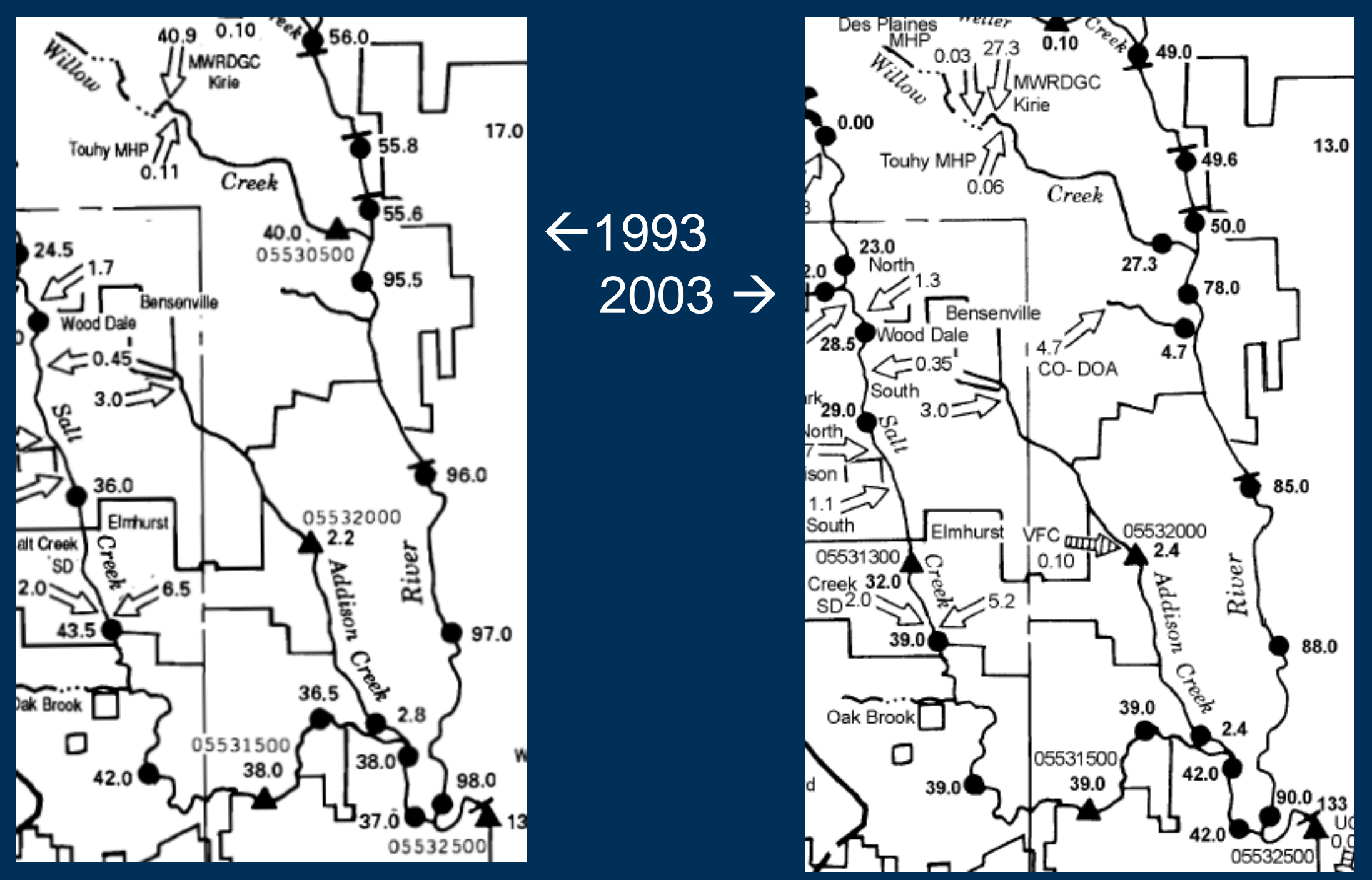

Notes:

- Channel losses in Lower Salt Creek in 1993 map but not 2003.

- Decrease in Kirie WWTP flows from 1993 to 2003, which explain part but not all of Des Plaines River decreases from 1993 to 2003. 


\section{Flow Data Sources and Computation Methods: Des Plaines River}

\begin{tabular}{|c|c|}
\hline Location & Data Source or Computation Method \\
\hline $\begin{array}{l}\text { Reach A: DPR below Salt Ck } \\
\text { confluence }\end{array}$ & Q $_{\text {DPR.Riverside }}$ \\
\hline $\begin{array}{l}\text { Reach B: DPR above Salt Ck } \\
\text { confluence / below Salt Ck } \\
\text { diversion }\end{array}$ & $\mathrm{Q}_{\text {DPR.abvSalt.MWRDdiv }}=\mathrm{Q}_{\text {DPR.Riverside }}-\mathrm{Q}_{\text {Saltck.conf }}$ \\
\hline $\begin{array}{l}\text { Reach C: DPR above Salt Ck } \\
\text { diversion }\end{array}$ & $\mathrm{Q}_{\mathrm{DPR} \text {.abvSalt }}=\mathrm{Q}_{\mathrm{DPR} \text {.Riverside }}-\mathrm{Q}_{\text {Saltck.conf }}-\mathrm{Q}_{\text {div }}$ \\
\hline \multicolumn{2}{|c|}{ 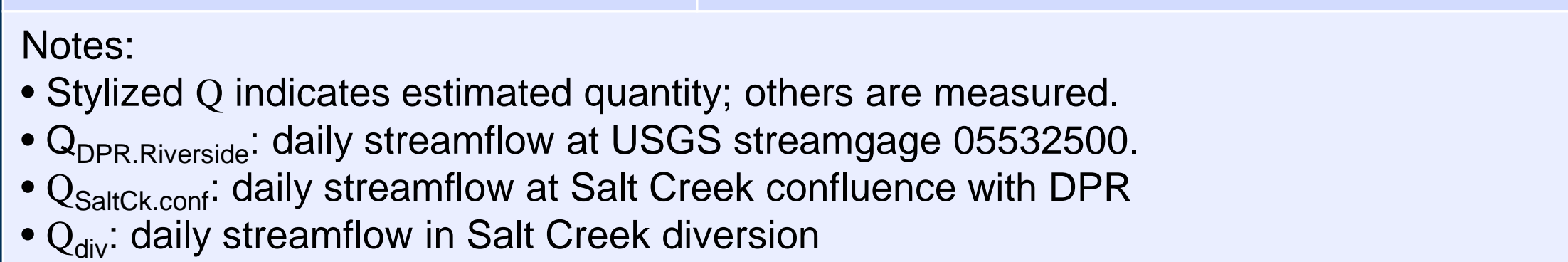 } \\
\hline
\end{tabular}




\section{Flow Data Sources and Computation Methods: Salt Creek}

\section{Location}

Salt Creek at confluence

\section{Data Source or Computation Method}

$\mathrm{Q}_{\text {Saltck.conf }}=K_{\mathrm{DA} \text {.adj.conf }}\left[\mathrm{Q}_{\text {Saltck.wSprings }}+\mathrm{Q}_{\text {Addisonck }}\right]-\mathrm{Q}_{\text {div, }}$ where $K_{\text {DA.adj.conf }}=\mathrm{DA}_{\text {Saltck.conf }}\left(\mathrm{DA}_{\text {SaltckWSprings }}+\mathrm{DA}_{\text {Addisonck }}\right)=$ $150.4 /(116.3+16.2)=1.135$;

$K_{\text {DA.adj.conf }}=1$ for no ungaged area adjustment.

Salt Creek diversion

$$
\begin{aligned}
& \mathrm{Q}_{\text {div }}=K_{\text {rating }}{ }^{*} \mathrm{Q}_{\text {Saltck.at.div }} \\
& K_{\text {rating }}=0.449 \text { (MWRD) or } 0.0 \text { (IDNR-OWR) }
\end{aligned}
$$

Salt Creek at diversion

$\mathrm{Q}_{\text {Saltck.at.div }}=K_{\mathrm{DA} \text {.adj.div }}\left[\mathrm{Q}_{\text {Saltck.wSprings }}+\mathrm{Q}_{\text {Addisonck }}\right]$, where $K_{\text {DA.adj.div }}=\mathrm{DA}_{\text {Saltck.at.div }} /\left(\mathrm{DA}_{\text {SaltckWSprings }}+\mathrm{DA}_{\text {Addisonck }}\right)=$ $145.3 /(116.3+16.2)=1.0966$; $K_{\text {DA.adj.div }}=1$ for no ungaged area adjustment.

Notes:

- Stylized Q indicates estimated quantity; others are measured.

- $Q_{\text {Addisonck: }}$ daily streamflow at USGS streamgage 05532000.

- Q Qaltck.wSprings: daily streamflow at USGS streamgage 05531500.

- DA: drainage areas in square miles from USGS StreamStats. 


\section{Trend Analysis: Annual Minimum 7-Day Flow (Q7), WY 1980-2010}

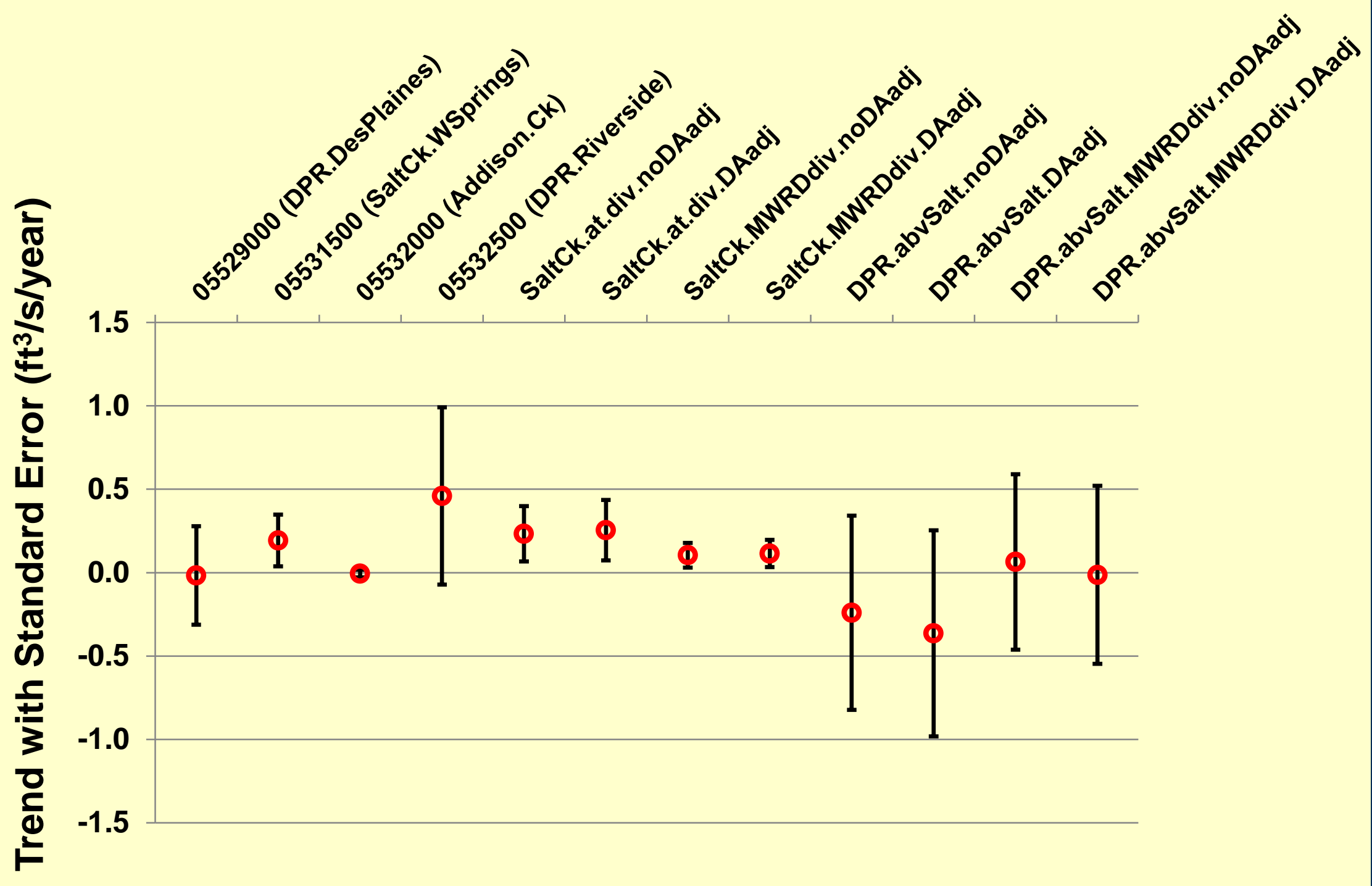




\section{Computation of 7Q10:}

\section{log-Pearson type 3 (LP3) Method}

- Determine a homogeneous period (here 1980-2010)

- Compute moments (mean, stdev, skewness) of $^{\log _{10}}$ of annual minimum 7-day flow $\left(\log _{10} Q 7\right)$ series

- Fit to "Pearson type 3" distribution using moments to constrain parameters (in this study function quape30) from version 1.6.1 of Imomco package (Asquith, 2012) of $R$ language was used for this fit).

- Note: Flood frequency computations are usually done essentially the same way (Interagency Advisory Committee on Water Data, 1981).

\section{₹USGS}




\section{Computation of 7Q10: Example Fits}

\section{Salt Ck at WesternSprings (05531500)}

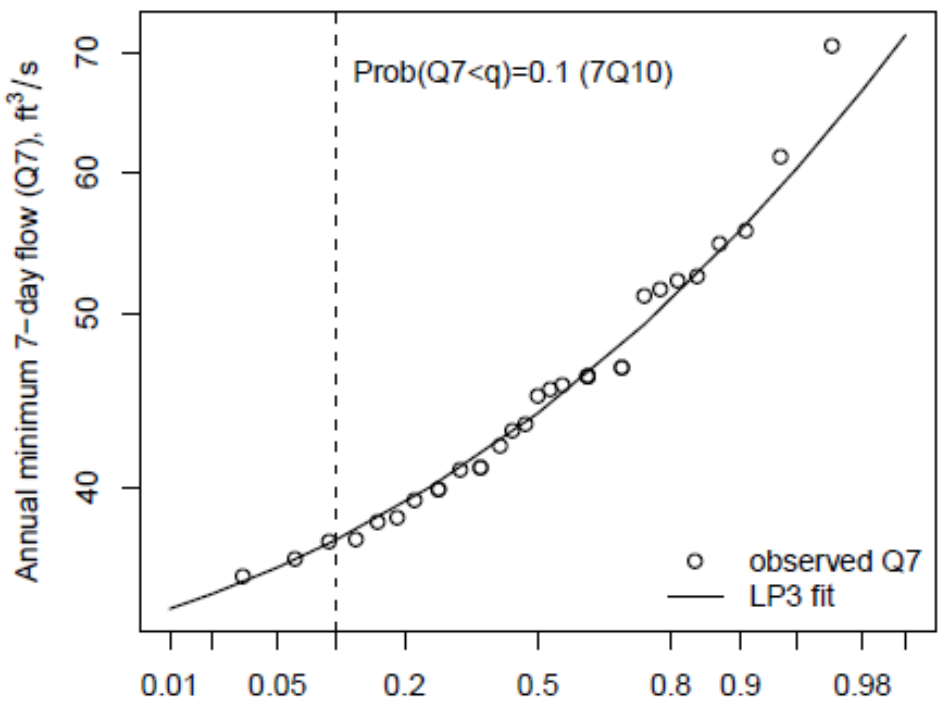

DPR above Salt Ck, adjusted for ungaged area

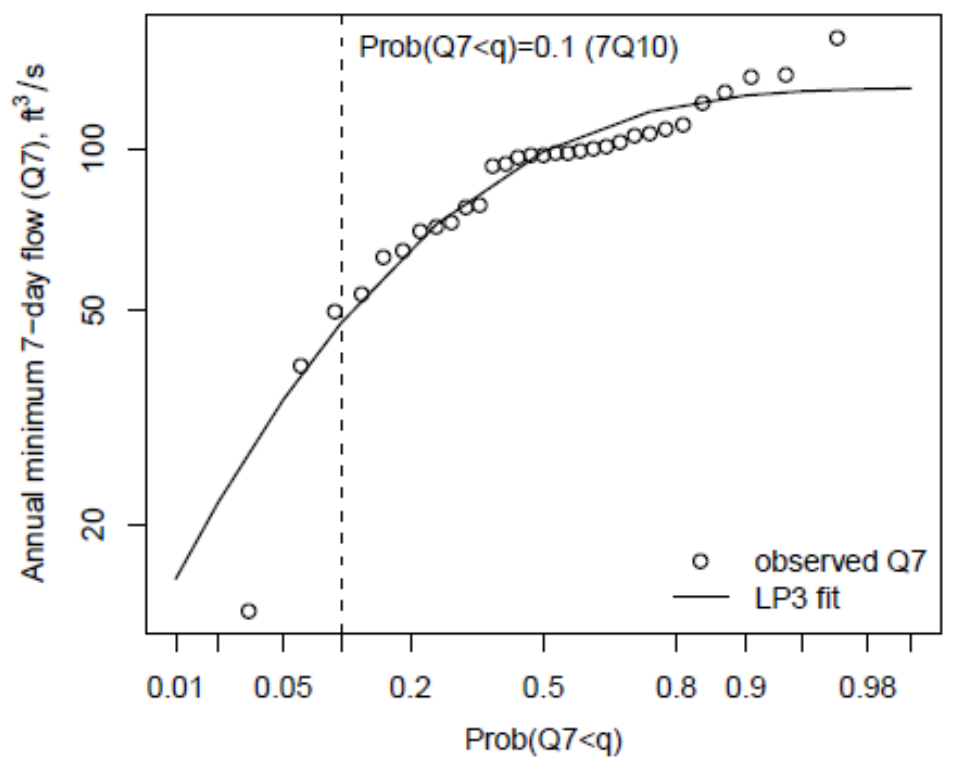

DPR at Riverside (05532500)

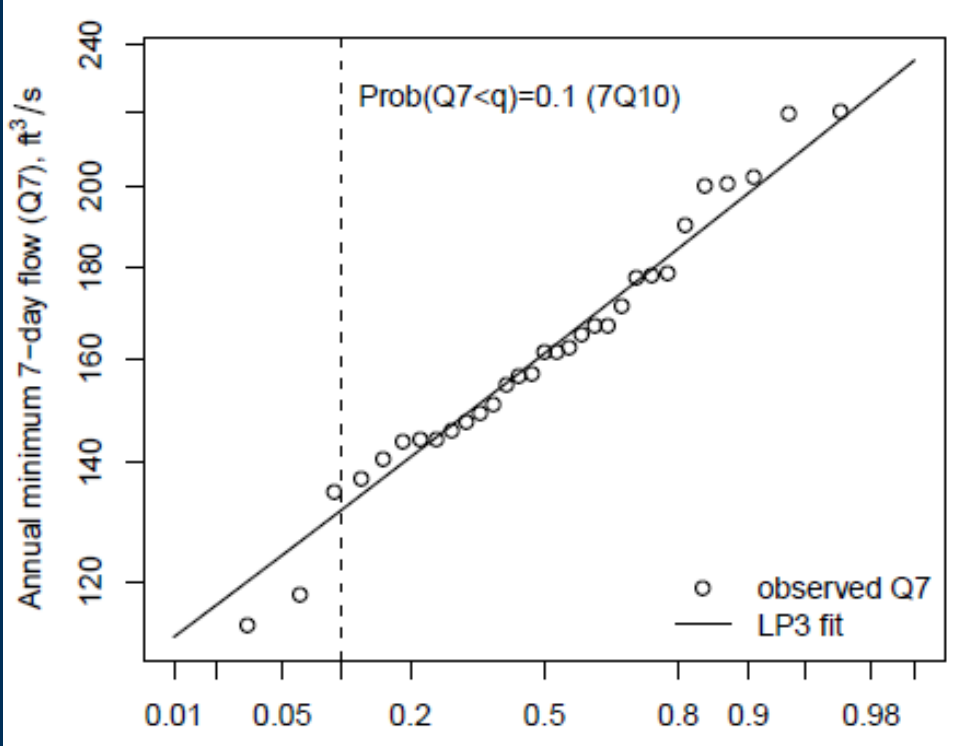

DPR above Salt Ck, MWRD diversion rating, adjusted for ungaged area

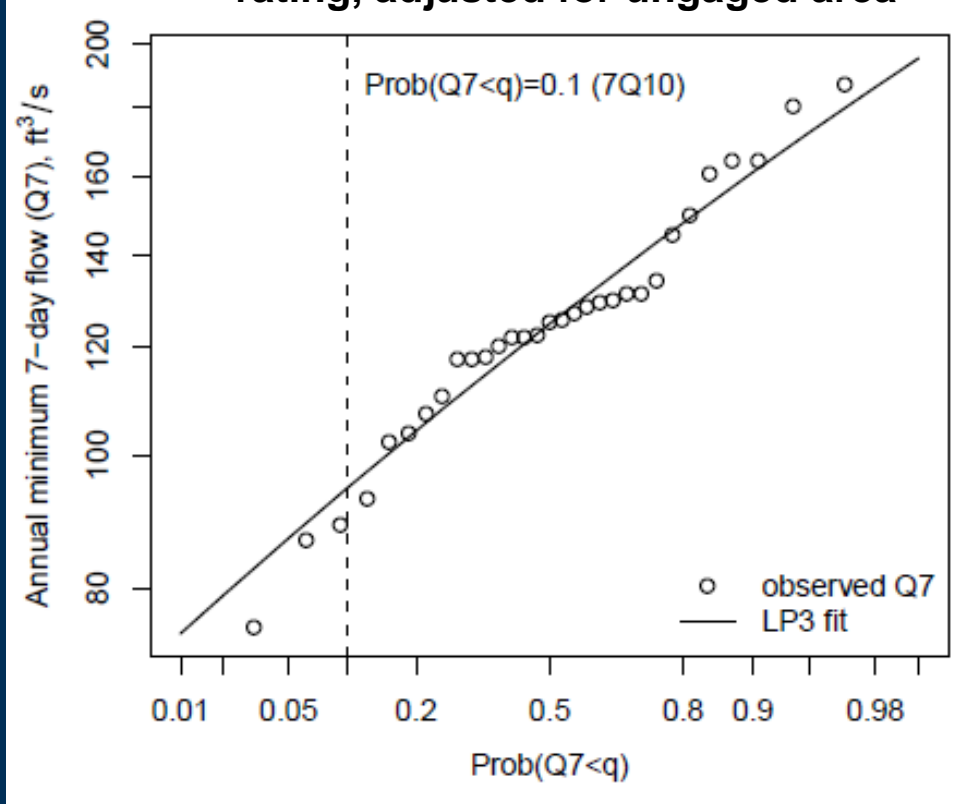




\section{Computation of 7Q10: Results}

\begin{tabular}{|c|c|c|c|c|}
\hline $\begin{array}{l}\text { Applicable Des } \\
\text { Plaines River } \\
\text { reach }\end{array}$ & $\begin{array}{l}\text { Drainage area } \\
\text { adjustment }\end{array}$ & $\begin{array}{l}\text { Salt Creek } \\
\text { diversion } \\
\text { included }\end{array}$ & $\begin{array}{l}\text { Estimated } \\
\text { 7Q10: this } \\
\text { study }\left(\mathrm{ft}^{3} / \mathrm{s}\right)\end{array}$ & $\begin{array}{l}\text { Estimated } \\
\text { 7Q10: ISWS } \\
2003\left(\mathrm{ft}^{3} / \mathrm{s}\right)\end{array}$ \\
\hline \multirow[t]{2}{*}{$\begin{array}{l}\text { Reach A: } \\
\text { below Salt Ck }\end{array}$} & N/A & $\mathrm{N} / \mathrm{A}$ & 131 & 133 \\
\hline & No & Yes & 101 & 90 \\
\hline \multirow{3}{*}{$\begin{array}{l}\text { Reach } B \text { : } \\
\text { above Salt Ck, } \\
\text { below diversion }\end{array}$} & Yes & Yes & 94.5 & 90 \\
\hline & No & No & 62.0 & 90 \\
\hline & Yes & No & 47.3 & 90 \\
\hline \multirow{2}{*}{$\begin{array}{l}\text { Reach C: } \\
\text { above Salt Ck, } \\
\text { above diversion }\end{array}$} & No & $\mathrm{N} / \mathrm{A}$ & 62.0 & 88 \\
\hline & Yes & N/A & 47.3 & 88 \\
\hline
\end{tabular}




\section{Daily Flow Quantiles: Computation Example}

DPR.Riverside (05532500), WY 2000-2010

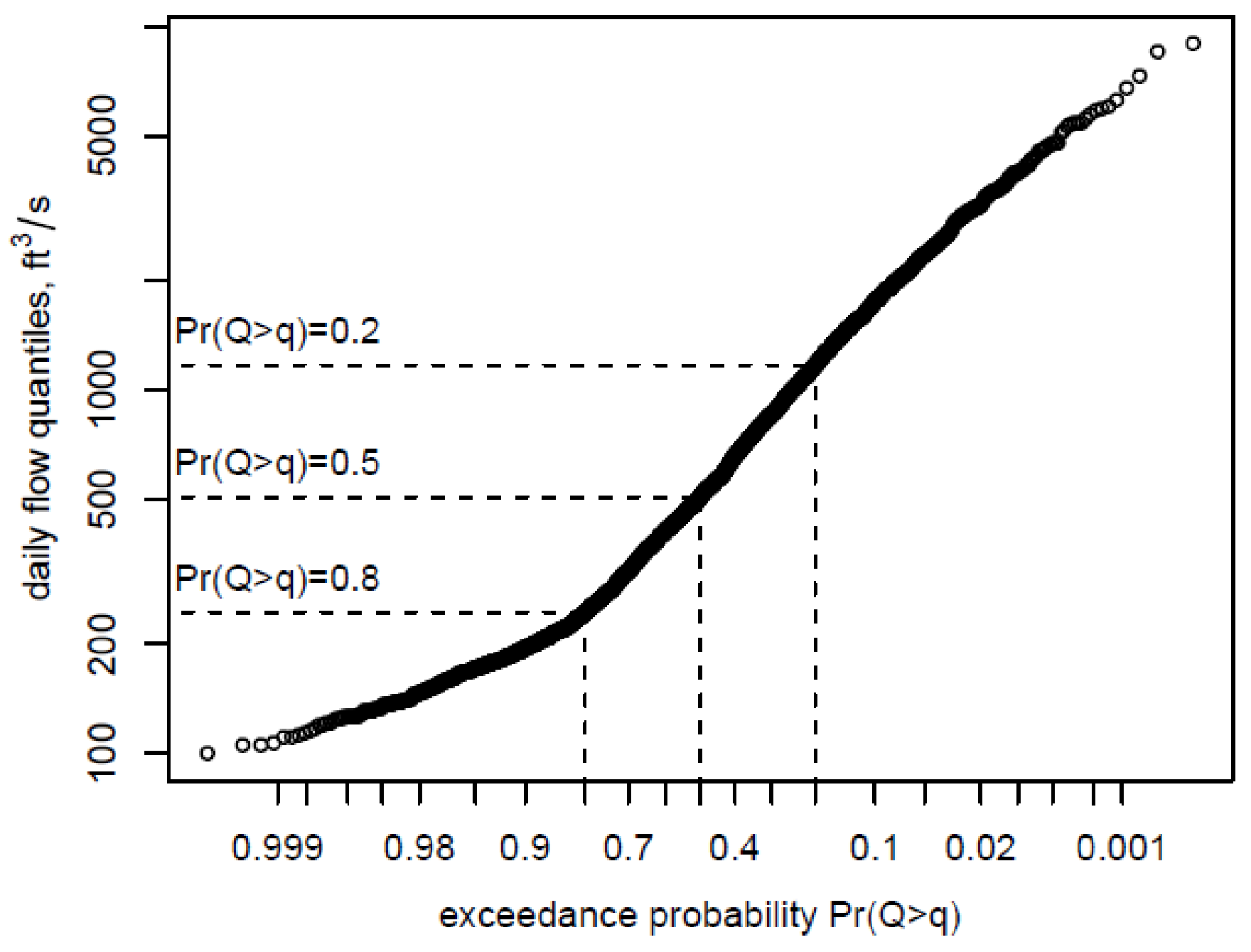


Trend Analysis of Daily Flow Quantiles Method

- Example computation plot in previous slide used 11 years of data.

- To analyze trends, daily flow quantiles were obtained from each water year's data separately to obtain quantiles on an annual basis.

- Example results of trend analysis of these annual quantiles for $\mathbf{5 0 \%}$ and $\mathbf{2 0 \%}$ exceedance probabilities are given in the following slides; $80 \%$ exceedance results were given in main body of presentation. 


\section{Trend Analysis: Annual Quantiles of 50\% Exceedance Daily Flow}
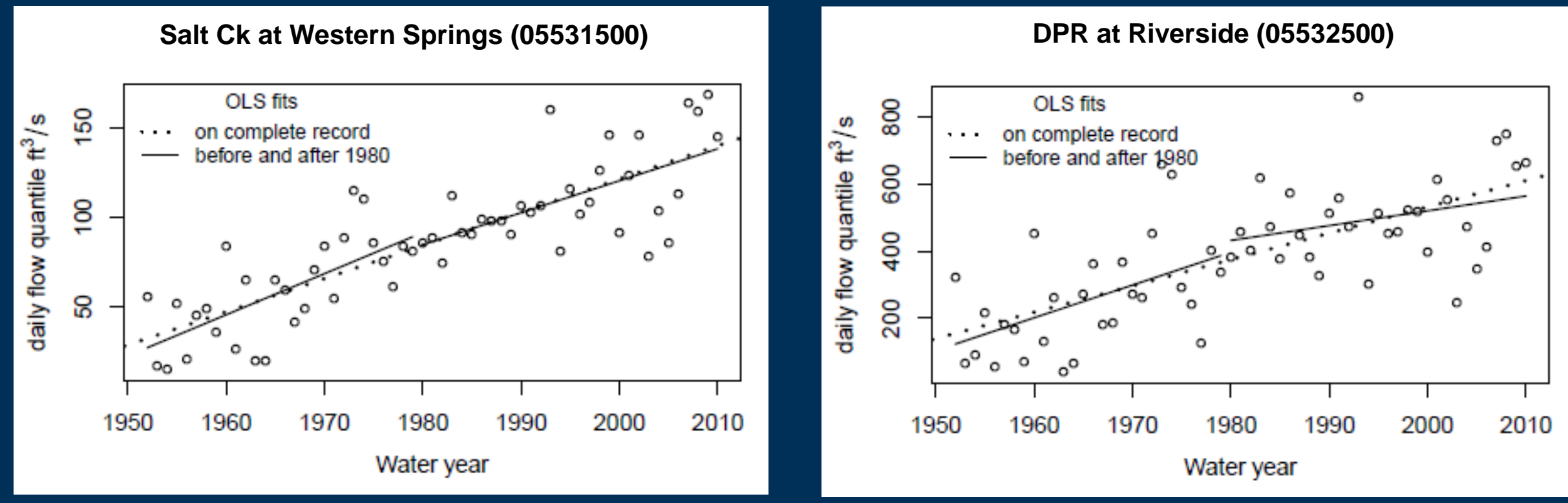

DPR above Salt Ck, adjusted for ungaged area

DPR above Salt Ck, MWRD diversion rating, adjusted for ungaged area
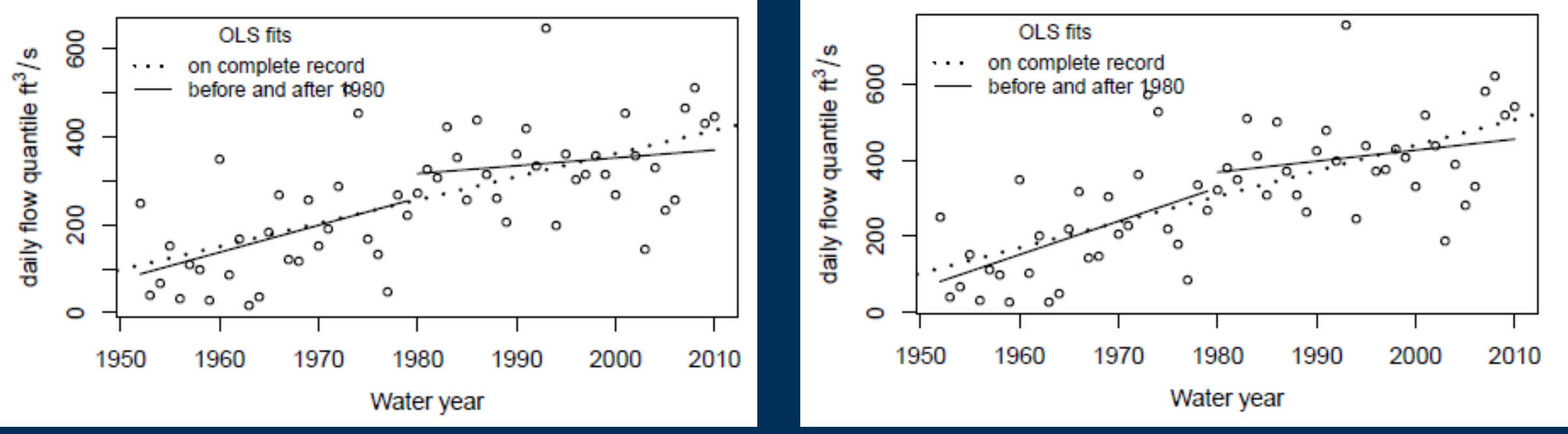


\section{Trend Analysis: Annual Quantiles of $20 \%$ Exceedance Daily Flow}

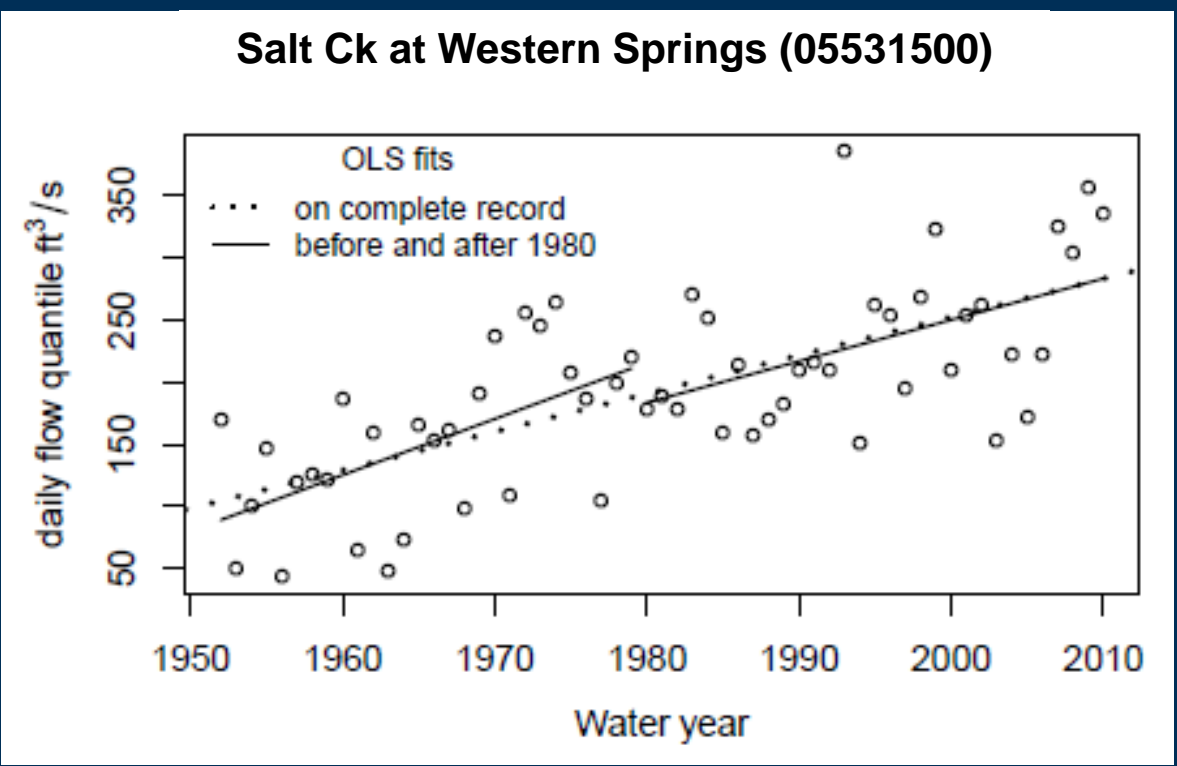

DPR above Salt Ck, adjusted for ungaged area

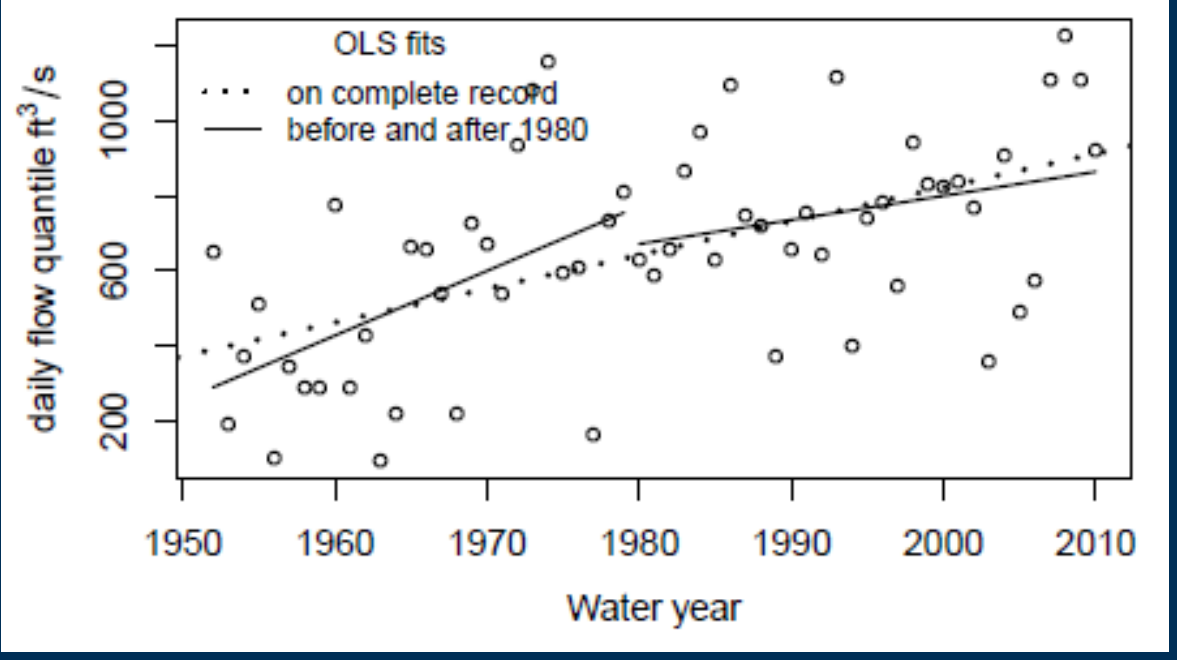

\section{DPR at Riverside (05532500)}

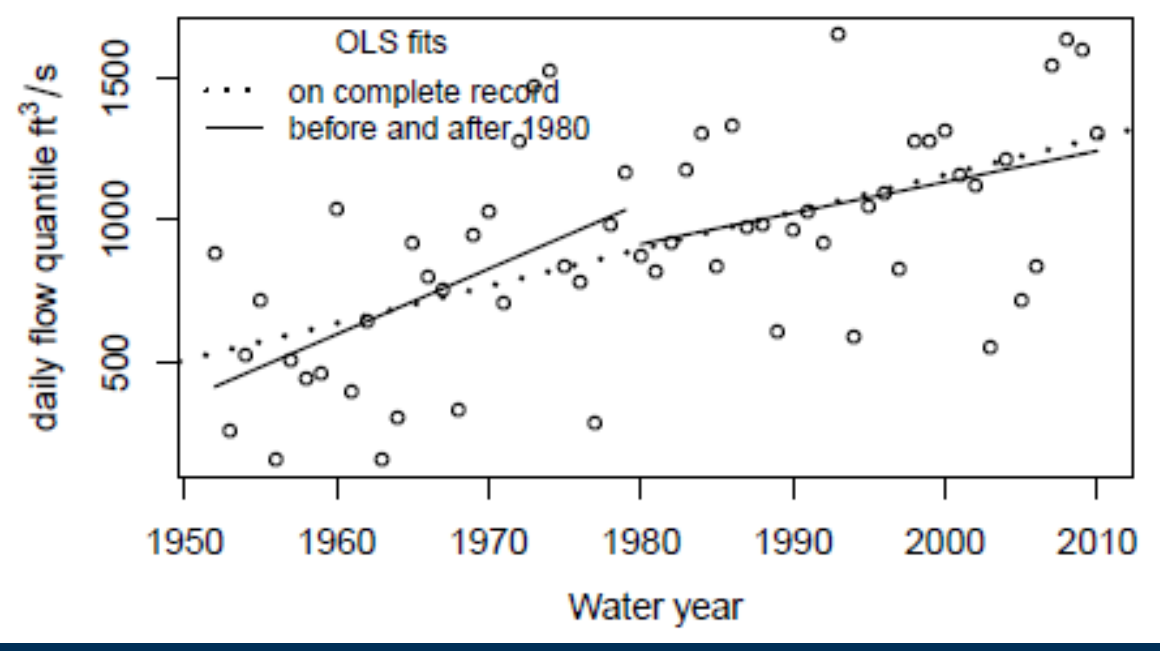

DPR above Salt Ck, MWRD diversion rating, adjusted for ungaged area

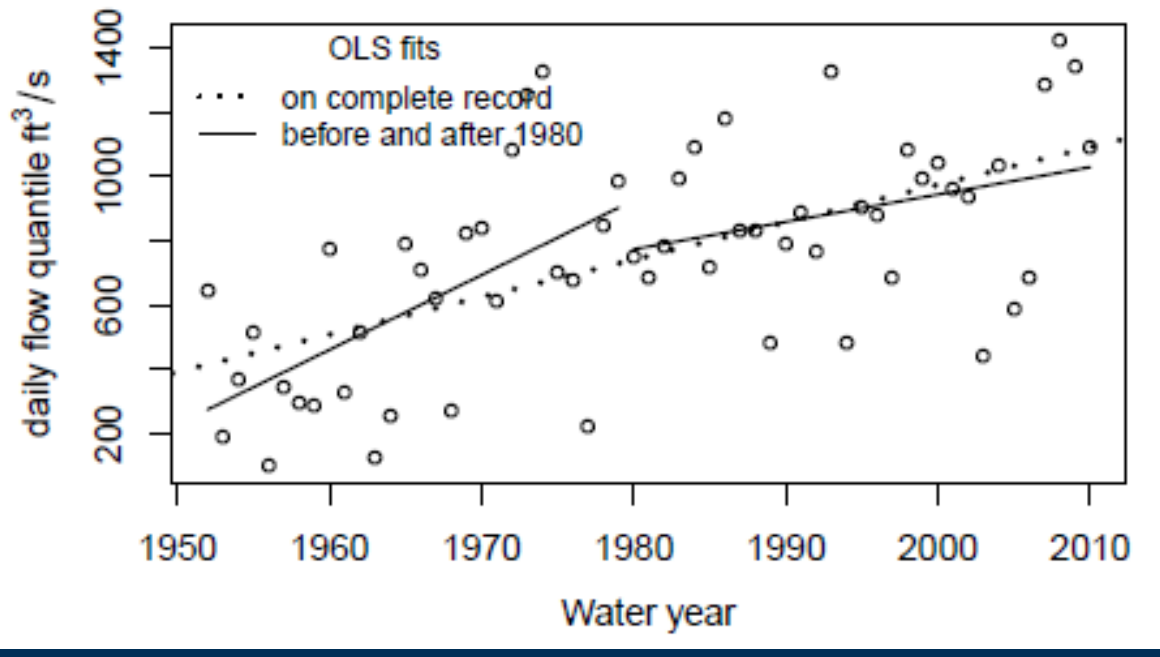




\section{Trend Analysis: Annual Quantiles of $80 \%$ Exceedance Daily Flow, WY 1980-2010}

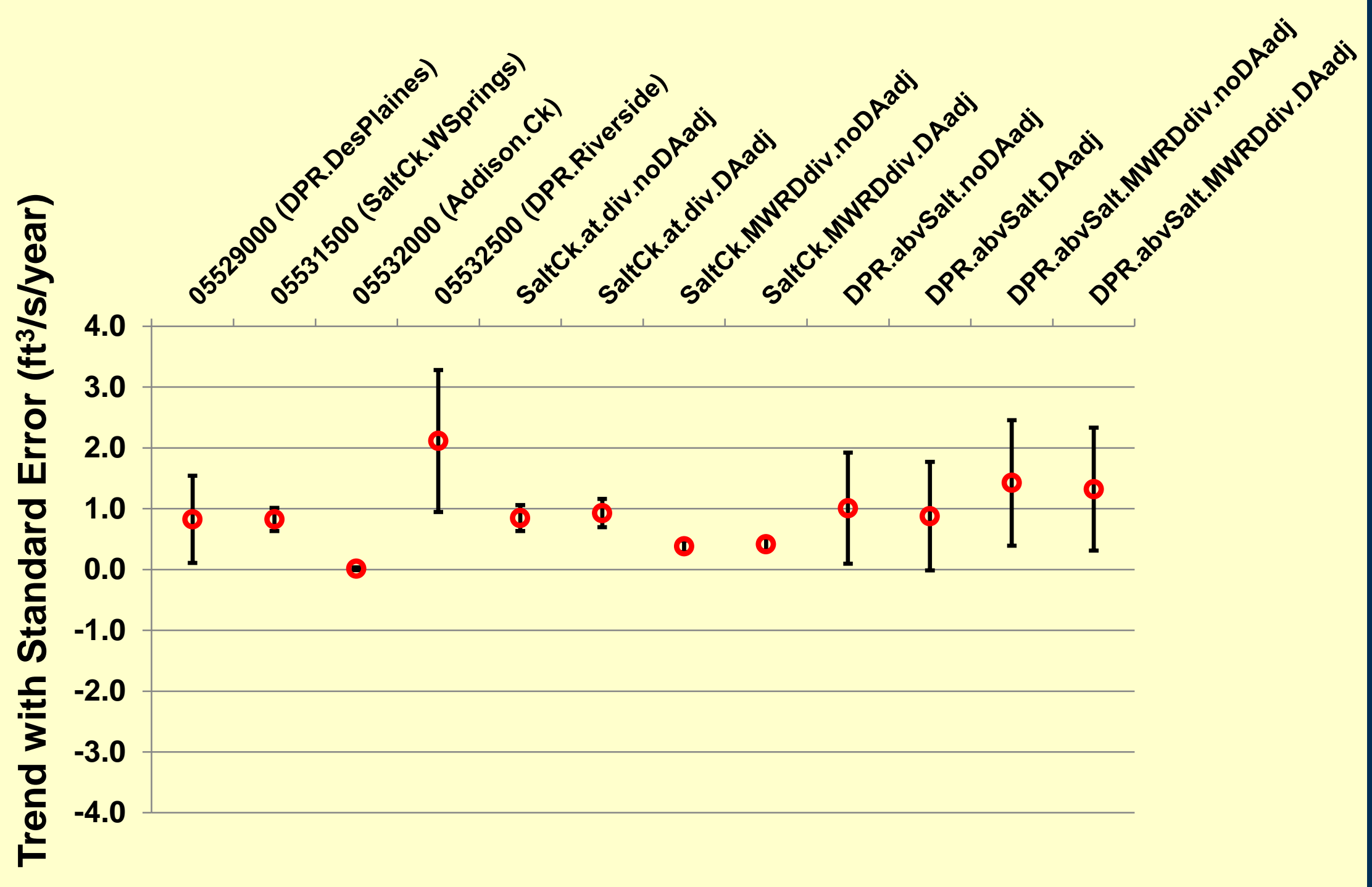




\section{Trend Analysis: Annual Quantiles of 50\% Exceedance Daily Flow, WY 1980-2010}

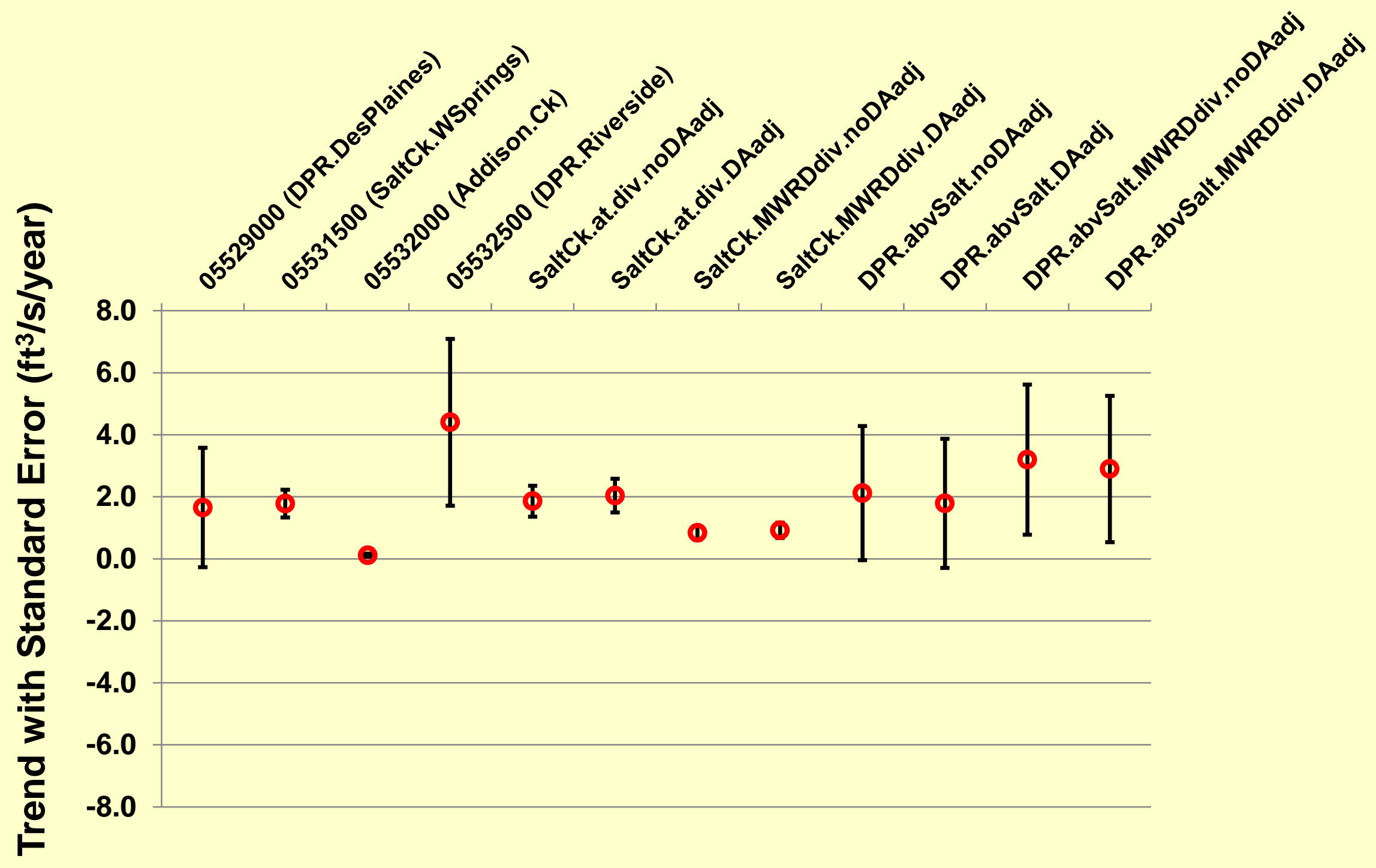




\section{Trend Analysis: Annual Quantiles of $20 \%$ Exceedance Daily Flow, WY 1980-2010}

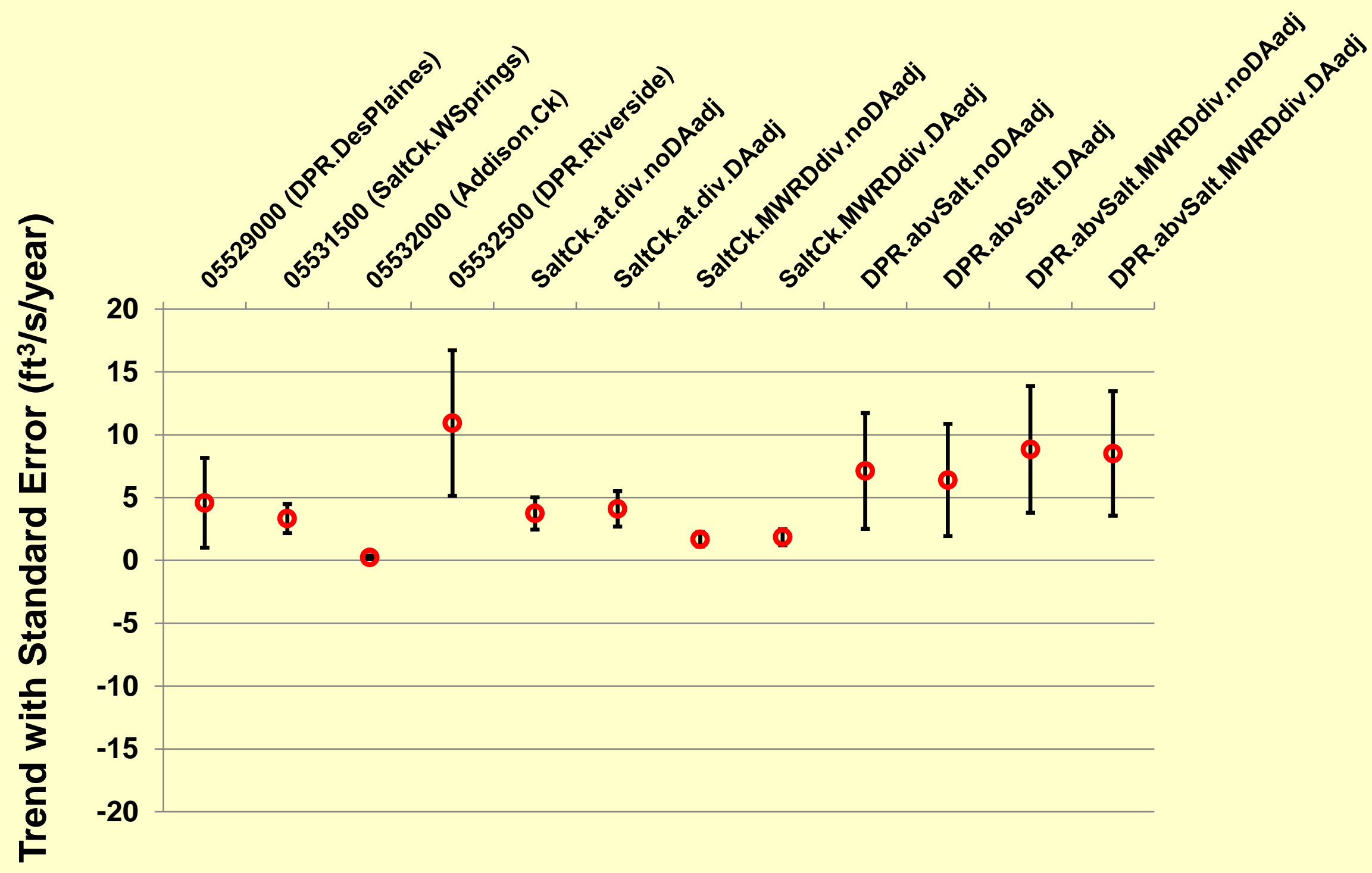




\section{Computation of Daily Flow Quantiles: Results}

\begin{tabular}{|c|c|c|c|c|}
\hline Location & $\begin{array}{c}\text { Applicable Des Plaines } \\
\text { River reach }\end{array}$ & $\begin{array}{l}Q_{0.80} \\
\left(\mathrm{ft}^{3} / \mathrm{s}\right)\end{array}$ & $\begin{array}{c}Q_{0.50} \\
\left(f^{3} / s\right)\end{array}$ & $\begin{array}{c}Q_{0.20} \\
\left(f^{3} / s\right)\end{array}$ \\
\hline DPR.Riverside & Below Salt Ck (Reach A) & $\begin{array}{c}245 \\
(246)\end{array}$ & $\begin{array}{l}508 \\
(507)\end{array}$ & $\begin{array}{c}1170 \\
(1170)\end{array}$ \\
\hline $\begin{array}{l}\text { DPR.abv.SaltCk. } \\
\text { O WRDdiv.noDAadj }\end{array}$ & \multirow{2}{*}{$\begin{array}{l}\text { Above Salt Ck, below } \\
\text { diversion (Reach B) }\end{array}$} & 199 & 425 & 1000 \\
\hline $\begin{array}{l}\text { DPR.abv.SaltCk. } \\
\text { O WRDdiv.DAadj }\end{array}$ & & 191 & 412 & 977 \\
\hline $\begin{array}{l}\text { DPR.abv.SaltCk.no } \\
\text { DAadj }\end{array}$ & \multirow{2}{*}{$\begin{array}{l}\text { Above Salt Ck, above } \\
\text { diversion (Reach } \mathrm{C} \text { ) or no } \\
\text { diversion (Reach } \mathrm{B})\end{array}$} & $\begin{array}{c}160 \\
(161)\end{array}$ & $\begin{array}{c}358 \\
(358)\end{array}$ & $\begin{array}{c}863 \\
(863)\end{array}$ \\
\hline $\begin{array}{l}\text { DPR.abv.SaltCk. } \\
\text { ' \$adj }\end{array}$ & & 149 & 339 & 816 \\
\hline \multicolumn{5}{|c|}{$\begin{array}{l}\text { Note: Values in italics are from IDNR-OWR presentation (Sept. 2011) and were } \\
\text { computed using data from CY2000-9. These values are included for comparison } \\
\text { purposes only. }\end{array}$} \\
\hline
\end{tabular}




\section{Hydraulic Appendix}




\section{Summary Table for $\mathbf{8 0}$ th Percentile Flows}

\begin{tabular}{|c|c|c|c|c|c|c|c|c|c|c|}
\hline \multirow[b]{3}{*}{ Location and Cross Section } & \multicolumn{2}{|c|}{ Flow $\left(\mathrm{ft}^{3} / \mathrm{s}\right)$} & \multicolumn{4}{|c|}{ Top Width (ft) } & \multicolumn{4}{|c|}{ Maximum Depth (ft) } \\
\hline & \multirow{2}{*}{\begin{tabular}{|c} 
Diversion \\
Added
\end{tabular}} & \multirow{2}{*}{\begin{tabular}{c|c} 
No \\
Diversion
\end{tabular}} & \multicolumn{2}{|c|}{ Diversion Added } & \multicolumn{2}{|c|}{ No Diversion } & \multicolumn{2}{|c|}{ Diversion Added } & \multicolumn{2}{|c|}{ No Diversion } \\
\hline & & & Existing & Project & Existing & Project & Existing & Project & Existing & Project \\
\hline \multicolumn{11}{|l|}{\begin{tabular}{|l|l} 
31st Street to 26th Street \\
\end{tabular}} \\
\hline 16197 & 149 & 149 & 169.60 & 167.53 & 165.48 & 162.06 & 5.33 & 5.18 & 5.07 & 4.88 \\
\hline 14792 & 199 & 149 & 120.42 & 115.97 & 112.81 & 106.96 & 5.59 & 5.43 & 5.32 & 5.11 \\
\hline 13666 & 199 & 149 & 90.70 & 86.93 & 87.04 & 82.16 & 3.10 & 2.87 & 2.88 & 2.58 \\
\hline 12492 & 199 & 149 & 119.33 & 93.85 & 114.95 & 86.00 & 2.44 & 1.64 & 2.33 & 1.35 \\
\hline Average & --- & --- & 125.01 & 116.07 & 120.07 & 109.30 & 4.12 & 3.78 & 3.90 & 3.48 \\
\hline \multicolumn{11}{|l|}{ Railroad to 31st Street } \\
\hline 11518 & 199 & 149 & 121.65 & 110.95 & 120.91 & 107.37 & 3.79 & 2.8 & 3.70 & 2.5 \\
\hline 10591 & 199 & 149 & 95.41 & 78.79 & 94.84 & 70.58 & 3.79 & 2.43 & 3.74 & 2.18 \\
\hline 9682 & 199 & 149 & 148.95 & 117.66 & 147.78 & 115.09 & 4.62 & 3.15 & 4.57 & 2.94 \\
\hline 8907 & 199 & 149 & 98.48 & 87.51 & 98.17 & 86.26 & 6.24 & 4.73 & 6.21 & 4.53 \\
\hline Average & --- & --- & 116.12 & 98.73 & 115.43 & 94.83 & 4.61 & 3.28 & 4.56 & 3.04 \\
\hline \multicolumn{11}{|l|}{ Salt Creek to Railroad } \\
\hline 7978 & 199 & 149 & 139.56 & 104.90 & 138.65 & 100.59 & 4.59 & 3.04 & 4.56 & 2.86 \\
\hline 7387 & 199 & 149 & 115.59 & 80.81 & 114.75 & 79.19 & 4.33 & 2.61 & 4.31 & 2.49 \\
\hline 6042 & 199 & 149 & 190.33 & 137.59 & 190.22 & 136.85 & 4.79 & 2.97 & 4.79 & 2.90 \\
\hline 5688 & 199 & 149 & 159.61 & 127.52 & 159.59 & 126.43 & 4.12 & 2.24 & 4.11 & 2.20 \\
\hline Average & --- & --- & 151.27 & 112.71 & 150.80 & 110.77 & 4.46 & 2.72 & 4.44 & 2.61 \\
\hline \multicolumn{11}{|l|}{ Hofmann Dam to Salt Creek } \\
\hline 4804 & 245 & 245 & 99.05 & 77.65 & --- & --- & 4.74 & 2.51 & --- & --- \\
\hline 3542 & 245 & 245 & 94.22 & 57.53 & --- & --- & 6.08 & 3.3 & --- & --- \\
\hline 2691 & 245 & 245 & 226.96 & 91.79 & --- & --- & 6.65 & 2.77 & --- & --- \\
\hline 1682 & 245 & 245 & 368.43 & 97.33 & --- & --- & 7.86 & 1.42 & --- & --- \\
\hline Average & --- & --- & 197.17 & 81.08 & & & 6.33 & 2.50 & & \\
\hline
\end{tabular}




\section{Summary Table for $50^{\text {th }}$ Percentile Flows}

\begin{tabular}{|c|c|c|c|c|c|c|c|c|c|c|}
\hline \multirow[b]{3}{*}{ Location and Cross Section } & \multicolumn{2}{|c|}{ Flow $\left(\mathrm{ft}^{3} / \mathrm{s}\right)$} & \multicolumn{4}{|c|}{ Top Width (ft) } & \multicolumn{4}{|c|}{ Maximum Depth $(\mathrm{ft})$} \\
\hline & \multirow{2}{*}{$\begin{array}{c}\text { Diversion } \\
\text { Added }\end{array}$} & \multirow{2}{*}{$\begin{array}{c}\text { No } \\
\text { Diversion }\end{array}$} & \multicolumn{2}{|c|}{ Diversion Added } & \multicolumn{2}{|c|}{ No Diversion } & \multicolumn{2}{|c|}{ Diversion Added } & \multicolumn{2}{|c|}{ No Diversion } \\
\hline & & & Existing & Project & Existing & Project & Existing & Project & Existing & Project \\
\hline \multicolumn{11}{|l|}{ 31st Street to 26th Street } \\
\hline 16197 & 339 & 339 & 176.29 & 175.97 & 175.50 & 175.12 & 6.44 & 6.32 & 6.15 & 6.01 \\
\hline 14792 & 425 & 339 & 140.29 & 138.57 & 136.32 & 134.25 & 6.64 & 6.50 & 6.33 & 6.16 \\
\hline 13666 & 425 & 339 & 106.35 & 103.09 & 101.93 & 98.06 & 4.06 & 3.86 & 3.79 & 3.55 \\
\hline 12492 & 425 & 339 & 135.63 & 125.67 & 132.03 & 119.91 & 3.31 & 2.78 & 3.12 & 2.47 \\
\hline Average & --- & --- & 139.64 & 135.83 & 136.45 & 131.84 & 5.11 & 4.87 & 4.85 & 4.55 \\
\hline \multicolumn{11}{|l|}{ Railroad to 31st Street } \\
\hline 11518 & 425 & 339 & 128.41 & 123.39 & 127.04 & 120.97 & 4.61 & 4.00 & 4.44 & 3.7 \\
\hline 10591 & 425 & 339 & 103.05 & 94.34 & 101.83 & 90.65 & 4.52 & 3.69 & 4.41 & 3.44 \\
\hline 9682 & 425 & 339 & 160.08 & 143.09 & 158.74 & 137.26 & 5.31 & 4.4 & 5.21 & 4.18 \\
\hline 8907 & 425 & 339 & 104.12 & 96.11 & 103.41 & 94.57 & 6.91 & 5.96 & 6.82 & 5.77 \\
\hline Average & --- & --- & 123.92 & 114.23 & 122.76 & 110.86 & 5.34 & 4.51 & 5.22 & 4.27 \\
\hline \multicolumn{11}{|l|}{ Salt Creek to Railroad } \\
\hline 7978 & 425 & 339 & 147.86 & 129.23 & 147.27 & 124.11 & 5.22 & 4.24 & 5.16 & 4.06 \\
\hline 7387 & 425 & 339 & 159.56 & 99.75 & 154.46 & 98.20 & 4.91 & 3.79 & 4.87 & 3.68 \\
\hline 6042 & 425 & 339 & 199.42 & 155.74 & 199.12 & 152.43 & 5.33 & 4.11 & 5.31 & 4.05 \\
\hline 5688 & 425 & 339 & 163.04 & 155.20 & 162.98 & 154.95 & 4.64 & 3.38 & 4.63 & 3.34 \\
\hline Average & --- & --- & 167.47 & 134.98 & 165.96 & 132.42 & 5.03 & 3.88 & 4.99 & 3.78 \\
\hline \multicolumn{11}{|l|}{ Hofmann Dam to Salt Creek } \\
\hline 4804 & 508 & 508 & 106.22 & 85.36 & --- & --- & 5.19 & 3.63 & --- & --- \\
\hline 3542 & 508 & 508 & 98.63 & 65.46 & --- & --- & 6.42 & 4.19 & --- & --- \\
\hline 2691 & 508 & 508 & 239.04 & 108.35 & --- & --- & 6.93 & 3.59 & --- & --- \\
\hline 1682 & 508 & 508 & 369.21 & 143.10 & --- & --- & 8.12 & 2.25 & --- & --- \\
\hline Average & --- & --- & 203.28 & 100.57 & & & 6.67 & 3.42 & & \\
\hline
\end{tabular}




\section{Summary Table for $20^{\text {th }}$ Percentile Flows}

\begin{tabular}{|c|c|c|c|c|c|c|c|c|c|c|}
\hline \multirow[b]{3}{*}{ Location and Cross Section } & \multicolumn{2}{|c|}{ Flow $\left(\mathrm{ft}^{3} / \mathrm{s}\right)$} & \multicolumn{4}{|c|}{ Top Width (ft) } & \multicolumn{4}{|c|}{ Maximum Depth (ft) } \\
\hline & \multirow{2}{*}{$\begin{array}{c}\text { Diversion } \\
\text { Added }\end{array}$} & \multirow{2}{*}{$\begin{array}{c}\text { No } \\
\text { Diversion }\end{array}$} & \multicolumn{2}{|c|}{ Diversion Added } & \multicolumn{2}{|c|}{ No Diversion } & \multicolumn{2}{|c|}{ Diversion Added } & \multicolumn{2}{|c|}{ No Diversion } \\
\hline & & & Existing & Project & Existing & Project & Existing & Project & Existing & Project \\
\hline \multicolumn{11}{|l|}{ 31st Street to 26th Street } \\
\hline 16197 & 816 & 816 & 320.33 & 254.84 & 181.93 & 180.06 & 8.3 & 8.19 & 7.92 & 7.79 \\
\hline 14792 & 1000 & 816 & 161.14 & 160.37 & 158.56 & 157.64 & 8.45 & 8.32 & 8.03 & 7.88 \\
\hline 13666 & 1000 & 816 & 138.03 & 135.98 & 134.81 & 129.50 & 5.78 & 5.60 & 5.41 & 5.20 \\
\hline 12492 & 1000 & 816 & 171.67 & 154.94 & 153.20 & 149.31 & 5.05 & 4.76 & 4.73 & 4.39 \\
\hline Average & --- & --- & 197.79 & 176.53 & 157.13 & 154.13 & 6.90 & 6.72 & 6.52 & 6.32 \\
\hline \multicolumn{11}{|l|}{ Railroad to 31st Street } \\
\hline 11518 & 1000 & 816 & 143.72 & 139.57 & 139.87 & 136.82 & 6.29 & 5.97 & 6.01 & 5.63 \\
\hline 10591 & 1000 & 816 & 122.30 & 115.38 & 117.27 & 112.53 & 6.1 & 5.7 & 5.88 & 5.43 \\
\hline 9682 & 1000 & 816 & 244.26 & 183.13 & 227.21 & 171.20 & 6.82 & 6.4 & 6.64 & 6.16 \\
\hline 8907 & 1000 & 816 & 116.49 & 112.75 & 115.17 & 110.94 & 8.37 & 7.93 & 8.21 & 7.71 \\
\hline Average & --- & --- & 156.69 & 137.71 & 149.88 & 132.87 & 6.90 & 6.50 & 6.69 & 6.23 \\
\hline \multicolumn{11}{|l|}{ Salt Creek to Railroad } \\
\hline 7978 & 1000 & 816 & 223.45 & 160.45 & 201.88 & 153.68 & 6.62 & 6.14 & 6.49 & 5.97 \\
\hline 7387 & 1000 & 816 & 281.22 & 225.01 & 261.04 & 215.40 & 6.24 & 5.70 & 6.16 & 5.58 \\
\hline 6042 & 1000 & 816 & 226.26 & 215.59 & 225.61 & 214.21 & 6.57 & 5.96 & 6.54 & 5.90 \\
\hline 5688 & 1000 & 816 & 174.83 & 166.99 & 174.21 & 166.76 & 5.85 & 5.21 & 5.84 & 5.18 \\
\hline Average & --- & --- & 226.44 & 192.01 & 215.69 & 187.51 & 6.32 & 5.75 & 6.26 & 5.66 \\
\hline \multicolumn{11}{|l|}{ Hofmann Dam to Salt Creek } \\
\hline 4804 & 1170 & 1170 & 120.58 & 109.93 & --- & --- & 6.24 & 5.42 & --- & --- \\
\hline 3542 & 1170 & 1170 & 111.55 & 89.16 & --- & --- & 7.15 & 5.70 & --- & --- \\
\hline 2691 & 1170 & 1170 & 249.84 & 141.52 & --- & --- & 7.51 & 4.90 & --- & --- \\
\hline 1682 & 1170 & 1170 & 370.71 & 158.79 & --- & --- & 8.61 & 3.57 & --- & --- \\
\hline Average & --- & --- & 213.17 & 124.85 & & & 7.38 & 4.90 & & \\
\hline
\end{tabular}




\section{Summary Table for 7Q10 Flows}

\begin{tabular}{|c|c|c|c|c|c|c|c|c|c|c|}
\hline \multirow[b]{3}{*}{ Location and Cross Section } & \multicolumn{2}{|c|}{ Flow $\left(\mathrm{ft}^{3} / \mathrm{s}\right)$} & \multicolumn{4}{|c|}{ Top Width (ft) } & \multicolumn{4}{|c|}{ Maximum Depth (ft) } \\
\hline & \multirow{2}{*}{$\begin{array}{c}\text { Diversion } \\
\text { Added }\end{array}$} & \multirow{2}{*}{$\begin{array}{c}\text { No } \\
\text { Diversion }\end{array}$} & \multicolumn{2}{|c|}{ Diversion Added } & \multicolumn{2}{|c|}{ No Diversion } & \multicolumn{2}{|c|}{ Diversion Added } & \multicolumn{2}{|c|}{ No Diversion } \\
\hline & & & Existing & Project & Existing & Project & Existing & Project & Existing & Project \\
\hline \multicolumn{11}{|l|}{ 31st Street to 26th Street } \\
\hline 16197 & 47.3 & 47.3 & 157.36 & 148.81 & 140.80 & 123.46 & 4.63 & 4.41 & 4.28 & 3.83 \\
\hline 14792 & 101 & 47.3 & 102.09 & 96.88 & 92.39 & 85.42 & 4.93 & 4.72 & 4.59 & 4.12 \\
\hline 13666 & 101 & 47.3 & 81.27 & 74.82 & 75.60 & 63.43 & 2.53 & 2.24 & 2.28 & 1.71 \\
\hline 12492 & 101 & 47.3 & 103.56 & 77.36 & 101.90 & 68.16 & 2.05 & 1.03 & 1.98 & 0.71 \\
\hline Average & --- & --- & 111.07 & 99.47 & 102.67 & 85.12 & 3.54 & 3.10 & 3.28 & 2.59 \\
\hline \multicolumn{11}{|l|}{ Railroad to 31st Street } \\
\hline 11518 & 101 & 47.3 & 118.73 & 96.78 & 118.24 & 82.43 & 3.43 & 2.07 & 3.37 & 1.56 \\
\hline 10591 & 101 & 47.3 & 91.75 & 64.17 & 91.06 & 59.33 & 3.49 & 1.64 & 3.46 & 1.23 \\
\hline 9682 & 101 & 47.3 & 141.35 & 108.29 & 140.68 & 103.55 & 4.34 & 2.38 & 4.31 & 2.03 \\
\hline 8907 & 101 & 47.3 & 96.19 & 82.65 & 96.01 & 80.48 & 5.97 & 3.97 & 5.95 & 3.64 \\
\hline Average & --- & --- & 112.01 & 87.97 & 111.50 & 81.45 & 4.31 & 2.52 & 4.27 & 2.12 \\
\hline \multicolumn{11}{|l|}{ Salt Creek to Railroad } \\
\hline 7978 & 101 & 47.3 & 131.85 & 91.15 & 131.34 & 80.92 & 4.33 & 2.31 & 4.31 & 2.00 \\
\hline 7387 & 101 & 47.3 & 104.55 & 70.40 & 104.37 & 65.89 & 4.09 & 1.9 & 4.08 & 1.70 \\
\hline 6042 & 101 & 47.3 & 187.84 & 129.79 & 187.80 & 128.61 & 4.57 & 2.29 & 4.57 & 2.17 \\
\hline 5688 & 101 & 47.3 & 158.41 & 113.12 & 158.40 & 112.11 & 3.90 & 1.57 & 3.89 & 1.48 \\
\hline Average & --- & --- & 145.66 & 101.12 & 145.48 & 96.88 & 4.22 & 2.02 & 4.21 & 1.84 \\
\hline \multicolumn{11}{|l|}{ Hofmann Dam to Salt Creek } \\
\hline 4804 & 131 & 131 & 95.97 & 72.41 & --- & --- & 4.54 & 1.82 & --- & --- \\
\hline 3542 & 131 & 131 & 92.14 & 52.85 & --- & --- & 5.93 & 2.72 & --- & --- \\
\hline 2691 & 131 & 131 & 217.97 & 79.90 & --- & --- & 6.51 & 2.25 & --- & --- \\
\hline 1682 & 131 & 131 & 367.55 & 76.04 & --- & --- & 7.73 & 1.00 & --- & --- \\
\hline Average & --- & --- & 193.41 & 70.30 & & & 6.18 & 1.95 & & \\
\hline
\end{tabular}




\section{Summary of Simulated Changes in Average Top Width and Maximum Depth}

\begin{tabular}{|c|c|c|c|c|c|c|c|c|}
\hline \multirow[b]{3}{*}{ Reach Location } & \multirow{2}{*}{\multicolumn{2}{|c|}{$\begin{array}{c}\text { 20th Percentile } \\
\text { Flows } \\
\text { (project minus } \\
\text { existing) } \\
\end{array}$}} & \multirow{2}{*}{\multicolumn{2}{|c|}{$\begin{array}{c}\text { 50th Percentile } \\
\text { Flows } \\
\text { (project minus } \\
\text { existing) } \\
\end{array}$}} & \multirow{2}{*}{\multicolumn{2}{|c|}{$\begin{array}{c}\text { 80th Percentile } \\
\text { Flows } \\
\text { (project minus } \\
\text { existing) } \\
\end{array}$}} & \multirow{2}{*}{\multicolumn{2}{|c|}{$\begin{array}{l}\text { 7Q10 Flows } \\
\text { (project minus } \\
\text { existing) }\end{array}$}} \\
\hline & & & & & & & & \\
\hline & \begin{tabular}{|c|} 
Average \\
Top \\
Width \\
Change \\
(ft)
\end{tabular} & $\begin{array}{c}\text { Average } \\
\text { Maximum } \\
\text { Depth } \\
\text { Change } \\
\text { (ft) } \\
\end{array}$ & $\begin{array}{l}\text { Average } \\
\text { Top } \\
\text { Width } \\
\text { Change } \\
\text { (ft) } \\
\end{array}$ & $\begin{array}{l}\text { Average } \\
\text { Maximum } \\
\text { Depth } \\
\text { Change } \\
\text { (ft) }\end{array}$ & \begin{tabular}{|l} 
Average \\
Top \\
Width \\
Change \\
(ft)
\end{tabular} & $\begin{array}{l}\text { Average } \\
\text { Maximum } \\
\text { Depth } \\
\text { Change } \\
\text { (ft) }\end{array}$ & $\begin{array}{l}\text { Average } \\
\text { Top } \\
\text { Width } \\
\text { Change } \\
\text { (ft) }\end{array}$ & $\begin{array}{l}\text { Average } \\
\text { Maximum } \\
\text { Depth } \\
\text { Change } \\
\text { (ft) }\end{array}$ \\
\hline $\begin{array}{l}\text { 31st Street to 26th } \\
\text { Street }\end{array}$ & -12.13 & -0.19 & -4.21 & -0.27 & -9.86 & -0.38 & -14.58 & -0.56 \\
\hline $\begin{array}{l}\text { Railroad to 31st } \\
\text { Street }\end{array}$ & -18.00 & -0.42 & -10.79 & -0.89 & -19.00 & -1.43 & -27.04 & -1.98 \\
\hline $\begin{array}{l}\text { Salt Creek to } \\
\text { Railroad } \\
\end{array}$ & -31.30 & -0.58 & -33.01 & -1.18 & -39.30 & -1.79 & -46.57 & -2.29 \\
\hline $\begin{array}{l}\text { Hofmann Dam to } \\
\text { Salt Creek }\end{array}$ & -88.32 & -2.48 & -102.71 & -3.25 & -116.09 & -3.83 & -123.11 & -4.23 \\
\hline
\end{tabular}




\section{Selected References}

- Asquith, W.H., 2012, Imomco---L-moments, trimmed L-moments, L-comoments, censored L-moments, and many distributions, in R package (version 1.6.1): Lubbock, Texas Tech University, accessed at

- Chow, V.T., 1959, Open channel hydraulics: New York, McGraw-Hill, 680 p.

- Easterling, D.R., and Peterson, T.C., 1995, A new method for detecting undocumented discontinuities in climatological time series: International Journal of Climatology, v. 15, p. 369-377.

- Illinois State Water Survey, 2003 (rev. Feb. 2003), 7-day 10-year low flows, Map 2, Northeastern Illinois Streams.

- Interagency Committee on Water Data, 1981, Guidelines for determining flood flow frequency: Bulletin 17B of the Hydrology Subcommittee, U.S. Department of the Interior, Geological Survey, Reston, Virginia [variously paged].

- Singh, K. P., and Ramamurthy, G.S., 1993, 7-day, 10-year low flows of streams in northeastern Illinois: Illinois State Water Survey Contract Report 545, 24 p.

- U.S. Army Corp of Engineers, Hydrologic Engineering Center, 2010, HEC-RAS river analysis system, hydraulic reference manual: version 4.1, various chapters plus appendixes.

- U.S. Geological Survey, Illinois StreamStats: accessed in May 2012 at 